\title{
Distribution of the heterotrophic dinoflagellate Pfiesteria piscicida in Korean waters and its consumption of mixotrophic dinoflagellates, raphidophytes and fish blood cells
}

\author{
Hae Jin Jeong ${ }^{1, *}$, Jeong Hyun Ha ${ }^{1}$, Jae Yeon Park ${ }^{2}$, Jong Hyeok Kim ${ }^{3}$, \\ Nam Seon Kang ${ }^{1}$, Sanghee Kim ${ }^{4}$, Jae Seong Kim ${ }^{1}$, Yeong Du Yoo', Won Ho Yih $^{5}$ \\ ${ }^{1}$ School of Earth and Environmental Sciences, College of Natural Sciences, Seoul National University, Seoul 151-747, ROK \\ ${ }^{2}$ Research Institute of Oceanography, College of Natural Sciences, Seoul National University, Seoul 151-747, ROK \\ ${ }^{3}$ Saemankeum Environmental Research Center, Kunsan National University, Kunsan 573-701, ROK \\ ${ }^{4}$ School of Biological Science, College of Natural Sciences, Seoul National University, Seoul 151-747, ROK \\ ${ }^{5}$ Department of Oceanography, Kunsan National University, Kunsan 573-701, ROK
}

\begin{abstract}
To explore the distribution of Pfiesteria piscicida in Korean coastal waters, we analyzed the morphology and DNA sequence of several isolates collected from 6 locations along the southern and western Korean coasts. We also investigated the prey species consumed by a Korean isolate and determined the growth and ingestion rates of $P$. piscicida when it fed on the dinoflagellate Amphidinium carterae, an unidentified cryptophyte species, and the raphidophyte Heterosigma akashiwo. Additionally, these parameters were measured when the isolate was fed perch blood cells and the cryptophyte Rhodomonas salina. Furthermore, we calculated grazing coefficients by combining field data on abundance of P. piscicida (and Pfiesteria-like dinoflagellates) with laboratory data on ingestion rates. The DNA sequence of a P. piscicida isolate from Masan Bay was identical to USA isolates, whereas DNA sequences of isolates from Busan, Incheon, Kunsan, Kwangyang, and Yeosu differed by $1 \mathrm{bp}$ from USA isolates. Among the prey offered, $P$. piscicida was able to feed on all naked mixotrophic dinoflagellates, the smallest thecate mixotrophic dinoflagellates Heterocapsa rotundata, and all raphidophytes, but not on large thecate dinoflagellates. Perch blood cells were the optimal prey. Maximum growth rates of $P$. piscicida fed on perch blood cells, $R$. salina, A. carterae, the cryptophyte, and $H$. akashiwo were $1.74,1.41,1.22,1.15$, and $1.10 \mathrm{~d}^{-1}$, respectively. The maximum ingestion rate of $P$. piscicida when fed perch blood cells (4.3 $\mathrm{ng} \mathrm{C}$ predator $^{-1} \mathrm{~d}^{-1}$ ) was much higher than those when fed $R$. salina, $H$. akashiwo, A. carterae, or the cryptophyte (0.4 to $\left.1.7 \mathrm{ng} \mathrm{C}_{\text {predator }}{ }^{-1} \mathrm{~d}^{-1}\right)$. Calculated grazing coefficients on co-occurring Amphidinium spp., H. akashiwo, and cryptophytes were up to $1.07,0.45$, and $0.22 \mathrm{~h}^{-1}$, respectively. Our results suggest that grazing by $P$. piscicida potentially has a considerable effect on algal populations.
\end{abstract}

KEY WORDS: Food web · Harmful algal bloom $\cdot$ Ingestion $\cdot$ Peduncle $\cdot$ Protist $\cdot$ Red tide

\section{INTRODUCTION}

The heterotrophic dinoflagellate Pfiesteria piscicida is known to form a bloom that is harmful to finfish (Burkholder et al. 1992, Glasgow et al. 2001) and shellfish (Springer et al. 1996). P. piscicida has been observed in many countries (Rublee et al. 2004,
2005); therefore, many sectors of the community around the globe are concerned about the appearance of $P$. piscicida in their coastal waters. However, its detailed distribution, morphological variations, and DNA sequences of isolates have been reported for only a few countries (Steidinger et al. 1996, 2001, Rublee et al. 1999, 2001a,b, 2005, Burkholder et al. 
2001a, Lewitus et al. 2002, Jakobsen et al. 2002, Rhodes et al. 2006).

The DNA sequences (small subunit [SSU], internal transcribed spacers [ITS] 1 and 2, $5.8 \mathrm{~S}$ rDNA, and large subunit [LSU]) of all USA isolates of Pfiesteria piscicida from several locations (e.g. GenBank accession numbers AF330600 to AF330620) were identical (summarized by Rublee et al. 2005), but differed slightly from that of a Norwegian isolate (GenBank accession number AY033488; Jakobsen et al. 2002). To determine the presence of $P$. piscicida in the waters of a region, and to explore the genetic relationships among isolates of $P$. piscicida from different locations in a region, their DNA sequences should be analyzed and compared to those of the USA and Norway isolates.

Pfiesteria piscicida feeds on prey using a peduncle after anchoring the prey by a tow filament (Burkholder \& Glasgow 1995), and is thus able to feed on diverse prey species within a wide size range: bacteria (Burkholder \& Glasgow 1995, 1997), cyanophytes (Burkholder \& Glasgow 1997, Glasgow et al. 1998), cryptophytes (Burkholder \& Glasgow 1997, Glasgow et al. 1998, Lewitus et al. 1999, Seaborn et al. 1999, 2001, Burkholder et al. 2001b, Parrow et al. 2001, Feinstein et al. 2002, Gransden \& Lewitus 2003, Lin et al. 2004), chrysophytes (Burkholder \& Glasgow 1997), diatoms (Glasgow et al. 1998, Burkholder et al. 2001b, Burkholder \& Glasgow 1995, 1997, Parrow et al. 2001, Seaborn et al. 2001), autotrophic nanoflagellates (Burkholder \& Glasgow 1997), ciliates (Burkholder \& Glasgow 1995), larvae of bivalves (Burkholder \& Glasgow 1997, Springer et al. 2002), the blood of finfish (Burkholder \& Glasgow 1997, Glasgow et al. 1998), and the epidermis, muscle, and gills of finfish (Burkholder \& Glasgow 1997) are known to be eaten. It has not yet been investigated whether mixotrophic dinoflagellates and/or raphidophytes are eaten by $P$. piscicida; this is, however, likely, because many mixotrophic dinoflagellate and raphidophyte species co-occur with $P$. piscicida, and these algae often provide a large amount of materials and energy to heterotrophic protistan grazers (e.g. Stoecker et al. 1981, Jeong \& Latz 1994, Kamiyama \& Arima 2001, Tillmann 2004).

Growth and/or ingestion rates of Pfiesteria piscicida have been reported for only a few prey items (Glasgow et al. 1998, Parrow et al. 2001, Seaborn et al. 2001, Feinstein et al. 2002, Lin et al. 2004); growth rates were reported when fed the cyanobacterium Synechococcus sp., the cryptophytes Rhodomonas spp. and Cryptomonas spp., and/or the diatom Thalassiosira weissflogii, whereas ingestion rates were reported when fed Rhodomonas spp. and/or the blood of fish or humans. Therefore, the limited number of prey species tested has constrained our understanding of the ecology of $P$. piscicida in marine ecosystems. Moreover, to date Lin et al. (2004) is the only report on the growth and ingestion rates of $P$. piscicida as a function of prey concentration, in which the growth and grazing rates on Rhodomonas sp. of $P$. piscicida isolated from USA waters is provided.

The overall objectives of the present study were to investigate the distribution of Pfiesteria piscicida in Korean waters, and to understand the feeding of Korean isolates on co-occurring mixotrophic dinoflagellates and raphidophytes and on fish blood. To investigate the distribution of $P$. piscicida in Korean waters, we took water samples from several locations along the coasts of the Korean peninsula, established several monoclonal cultures of $P$. piscicida and Pfiesteria-like dinoflagellates (PLDs), and then analyzed the morphology and DNA sequence of each isolate. In particular, in order to compare the DNA sequences of Korean isolates with those of the USA and Norway isolates, we analyzed ITS 1 and ITS 2, 5.8 S rDNA, LSU, and SSU. To understand the ecology of P. piscicida in Korean waters, we also examined (1) the kinds of prey on which a Korean isolate fed (prey species available: 12 mixotrophic dinoflagellates, 2 raphidophytes, 2 cryptophytes, 1 diatom species, and 3 different blood cells); (2) the growth and ingestion rates of $P$. piscicida fed 9 edible algal prey species at single prey concentrations; and (3) the numerical and functional responses of $P$. piscicida when fed the dinoflagellate Amphidinium carterae, an unidentified cryptophyte species (equivalent spherical diameter, ESD $=5.6 \mu \mathrm{m}$ ), the cryptophyte Rhodomonas salina, the raphidophyte Heterosigma akashiwo, and perch blood cells in the laboratory. Finally, we estimated grazing coefficients of $P$. piscicida on algal prey, by combining field data on the abundance of $P$. piscicida (and PLDs) and co-occurring dominant algae with laboratory data on ingestion rates obtained in the present study.

Based on the maximum growth and ingestion rates of Pfiesteria piscicida when fed diverse prey species, we determined the optimal prey supporting the maximum growth rate of $P$. piscicida that is comparable to or higher than that obtained when fed Rhodomonas sp., which has been known to be an optimal prey so far (Parrow et al. 2001, Lin et al. 2004). To understand the similarity in feeding between Korean and USA isolates of $P$. piscicida, the maximum growth and ingestion rates of the Korean isolate fed on $R$. salina (obtained in the present study) were compared to those of the USA isolate fed on Rhodomonas sp. The maximum growth and grazing rates of the Korean isolate fed on algal prey (obtained in the present study) were also compared to literature values of other heterotrophic and mixotrophic protists fed on the same prey. The results 
of the present study provide a basis for understanding the distribution of $P$. piscicida in Korean waters, interactions between $P$. piscicida and bloom-forming algal species, and the potential for $P$. piscicida to influence the population dynamics of algal prey.

\section{MATERIALS AND METHODS}

Isolation and culture of Pfiesteria piscicida. Using water samplers, plankton samples were collected from the surface waters off Busan, Incheon, Kunsan, Kwangyang, Masan, and Yeosu, Korea, in July 2005 (Fig. 1, Table 1). Those samples for the culture of living organisms were screened gently through a $154 \mu \mathrm{m}$ Nitex mesh and placed in three $270 \mathrm{ml}$ polycarbonate (PC) bottles. The first bottle was enriched with a mixture comprising an unidentified cryptophyte $(5.6 \mu \mathrm{m}$ in size), Rhodomonas salina, and Amphidinium carterae, and the second bottle was enriched with perch blood cells. The third bottle was not enriched and served as a control. The bottles were transported within $8 \mathrm{~h}$ to one of 2 laboratories (Seoul National University or Kunsan National University) by temperature-controlled cars $\left(20 \pm 2^{\circ} \mathrm{C}\right)$. Once in the laboratory, bottles were placed on plankton wheels rotating at $0.9 \mathrm{rpm}$, and were incu-

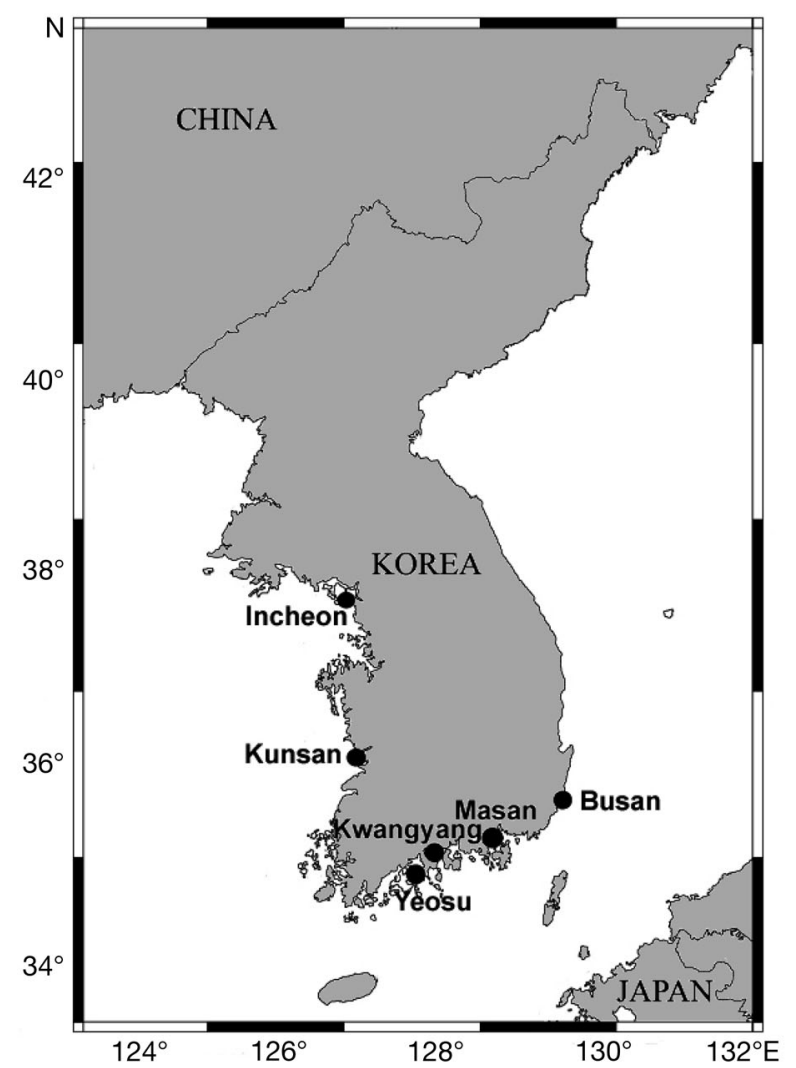

Fig. 1. Collection locations of Pfiesteria piscicida in Korea: Busan, Incheon, Kunsan, Kwangyang, Masan, and Yeosu bated at $20^{\circ} \mathrm{C}$ under an illumination of $20 \mu \mathrm{E} \mathrm{m}{ }^{-2} \mathrm{~s}^{-1}$ provided by cool white fluorescent light on a 14:10 h light:dark cycle. Each day, bottles were removed from the rotating wheels and examined under dissecting microscopes. Three to $7 \mathrm{~d}$ later, aliquots of enriched water were transferred to 6-well tissue culture plates, and monoclonal cultures of $P$. piscicida from each location were established via 2 serial single cell isolations. As concentrations of $P$. piscicida increased, these predators were sequentially transferred to $32,80,270$, and $500 \mathrm{ml}$ PC bottles containing A. carterae. Bottles were again filled to capacity with freshly filtered seawater, capped, and placed on a rotating wheel as described above. Once dense cultures of $P$. piscicida (ca. 10000 cells $\mathrm{ml}^{-1}$ ) were obtained, they were transferred to $500 \mathrm{ml} \mathrm{PC}$ bottles containing $A$. carterae (ca. 20000 to 30000 cells $\mathrm{ml}^{-1}$ ). The carbon content of $P$. piscicida was estimated from cell volume according to Menden-Deuer \& Lessard (2000).

Additionally, each sample for counting was transferred into a $100 \mathrm{ml}$ polyethylene (PE) bottle and preserved in $50 \%$ Bouin's solution (final conc.), into a $20 \mathrm{ml}$ scintillation vial and preserved in $1 \%$ glutaraldehyde (final conc.), into a $20 \mathrm{ml}$ scintillation vial and fixed in $4 \%$ formalin (final conc.), and into a $500 \mathrm{ml} \mathrm{PE}$ bottle and preserved in 5\% Lugol's solution (final conc.). The abundances of phototrophic plankton and heterotrophic protists were determined by enumerating cells in two $1 \mathrm{ml}$ Sedgwick-Rafter chambers (SRCs).

Morphology of Pfiesteria piscicida. Distilled water was added to a culture of each isolate of $P$. piscicida satiated with perch blood cells (final salinity: ca. $10 \mathrm{psu})$. The culture was fixed in $0.5 \% \mathrm{v} / \mathrm{v}$ formalin, and cells were stained with a drop of $10 \mu \mathrm{g} \mathrm{ml} \mathrm{m}^{-1}$ calcoflour white M2R before examination under an epifluorescence microscope.

For scanning electron microscopy (SEM), a $5 \mathrm{ml}$ aliquot of a dense culture of Pfiesteria piscicida was fixed using a cold double-fixation method modified from Steidinger et al. (1989). Fixed cells were rinsed 3 to 5 times with distilled water, dehydrated through an ethanol series, and finally critical-point-dried with carbon dioxide. Filters were mounted on a stub and coated with gold-palladium. Cells were viewed with a Jeol JSM-840 SEM and photographed with a Polaroid camera.

DNA extraction, PCR amplification, sequencing, and data analysis of Pfiesteria piscicida. For DNA extraction, cells of each isolate of $P$. piscicida starved for $2 \mathrm{~d}$ were collected by filtering approximately $50 \mathrm{ml}$ culture onto a $25 \mathrm{~mm}, 3 \mu \mathrm{m}$ pore size PC membrane. Genomic DNA was extracted with an UltraClean Soil DNA Kit (Mobio) following the manufacturer's instructions. 
Extracted DNA was divided into at least 5 PCR tubes, and more than 5 independent $\mathrm{PCR}$ reactions were performed for each isolate. The SSU, ITS 1, 5.8 S, ITS 2, and partial LSU rDNA were amplified using dinoflagellate universal primers and ITSR2 (forward: 5'-CAACCTGGTGATCCTGCCAGT-3'; reverse: 5'TCCCTGTTCATTCGCCATTAC-3') according to the method of Litaker et al. (2003). A $20 \mu \mathrm{l}$ PCR was mixed with the following reactants: $1 \times$ PCR buffer with $1.5 \mathrm{mM} \mathrm{MgCl}_{2}, 0.2 \mathrm{mM}$ dNTP, $0.5 \mu \mathrm{M}$ of each primer, 5 U Taq DNA polymerase (Bioneer), and $200 \mathrm{ng}$ template DNA. PCR cycles were performed in a UVIgeneflex Thermal cycler (UVITEC) under the following conditions: 1 initial cycle of $3 \mathrm{~min}$ at $94^{\circ} \mathrm{C}$; a series of 35 cycles of $30 \mathrm{~s}$ at $92^{\circ} \mathrm{C}, 45 \mathrm{~s}$ at $55^{\circ} \mathrm{C}$, and $3 \mathrm{~min}$ at $72^{\circ} \mathrm{C}$; and 1 extension cycle at $72^{\circ} \mathrm{C}$ for $10 \mathrm{~min}$. PCR products were cloned into the pGEM-T EASY vector (Promega). The cloned materials ( $>3$ clones for each independent $\mathrm{PCR}$ ) were incubated overnight in liquid $\mathrm{LB}$ media at $37^{\circ} \mathrm{C}$. Plasmids were extracted from these incubated materials using the AccuPrep Plasmid Extraction Kit (Bioneer). The presence of inserts into plasmids was ascertained by addition of EcoRI restriction endonuclease (Promega) to extracted plasmids. To determine the sequences of the internal fragments of the inserts, the internal primers G17F (5'-ATA CCG TCC TAG TCT TAA CC-3') and G18R (5'-GCA TCA CAG ACC TGT TAT TG-3') were used according to the method of Litaker et al. (2003). Sequencing of SSU, ITS 1, 5.8 S, ITS 2, and LSU rDNA was performed using an ABI PRISM 3700 DNA Analyzer (Applied Biosystems). All sequences were aligned using the ContigExpress alignment program (InforMax).

Preparation of prey. Phototrophic cells were grown at $20^{\circ} \mathrm{C}$ in enriched $\mathrm{f} / 2$ seawater media (Guillard \& Ryther 1962) without silicate, with continuous illumination of $20 \mu \mathrm{E} \mathrm{m} \mathrm{m}^{-2} \mathrm{~s}^{-1}$ provided by cool white fluorescent lights. Only cultures in the exponential growth phase were used for feeding experiments. The carbon contents of Heterosigma akashiwo $\left(0.1 \mathrm{ng} \mathrm{C} \mathrm{cell}{ }^{-1}, \mathrm{n}>\right.$ 2000), Rhodomonas salina (0.056 ng C cell $\left.{ }^{-1}, \mathrm{n}>2000\right)$, and an unidentified cryptophyte $\left(0.017 \mathrm{ng} \mathrm{C}\right.$ cell $^{-1}, \mathrm{n}>$ 2000) were estimated from cell volume according to Strathmann (1967).

Perch blood cells were obtained from adults by cutting the fin of the tail (ca. $50 \mathrm{~cm}$ ). The carbon content for perch blood cells (0.009 ng C cell $\left.{ }^{-1}, \mathrm{n}>2000\right)$ and Amphidinium carterae (0.07 ng C cell ${ }^{-1}, \mathrm{n}>2000$ ) was measured using a $\mathrm{CHN}$ analyzer (CM $5012 \mathrm{CO}_{2}$ Coulometer, UIC).

Expt 1 - Prey species consumed by Pfiesteria piscicida. Expt 1 was designed to investigate whether $P$. piscicida was able to feed on each target prey species (Table 2). The initial concentrations of each prey species offered were similar in terms of carbon biomass.
To confirm no ingestion of some prey species by $P$. piscicida, additional higher prey concentrations were provided. Mean prey size for each species ( $\mathrm{n}>2000$ ) was measured by an electronic particle counter (Coulter Multisizer II, Coulter Corporation).

A dense culture of Pfiesteria piscicida (strain PPIC0507), which had been growing on Amphidinium carterae and was then starved for $1 \mathrm{~d}$, was transferred to a 11 PC bottle containing freshly filtered seawater. Three $1 \mathrm{ml}$ aliquots were then removed from the bottle and examined using a compound microscope to determine the concentration of $P$. piscicida.

In this experiment, initial concentrations of Pfiesteria piscicida and each target prey species were established using an autopipette to deliver a predetermined volume of culture of known cell density to the experimental bottles. Duplicate $42 \mathrm{ml}$ PC bottles (mixtures of $P$. piscicida and target prey) and duplicate predator control bottles ( $P$. piscicida only) were set up for each target prey species. The bottles were filled to capacity with freshly filtered seawater, capped, and placed on a rotating wheel at $0.9 \mathrm{rpm}$ and incubated at $20^{\circ} \mathrm{C}$ under an illumination of $20 \mu \mathrm{E} \mathrm{m} \mathrm{m}^{-2} \mathrm{~s}^{-1}$ provided by cool white fluorescent light on a 14:10 h light:dark cycle. After 6, 12, 24, and 48 h incubation, a $5 \mathrm{ml}$ aliquot was removed from each bottle and transferred into a 6 -well plate chamber. Bottles were again filled to capacity with fresh f/2 medium, capped, and placed on the rotating wheel. For each target species, the feeding behavior of $>10 \mathrm{P}$. piscicida cells that were capturing prey cells and $>30$ unfed $P$. piscicida cells was then observed under a dissecting microscope at a magnification of 50 to $90 \times$, to determine whether $P$. piscicida was able to feed on the target prey species.

Expt 2-Comparison of growth and ingestion rates at single prey concentrations. Expt 2 was designed to compare the growth and ingestion rates of Pfiesteria piscicida when feeding on mixotrophic dinoflagellates (Amphidinium carterae, Heterocapsa rotundata, Cochlodinium polykrikoides, Akashiwo sanguinea, and Gymnodinium catenatum), raphidophytes (Chattonella ovata and Heterosigma akashiwo), cryptophytes (Rhodomonas salina and an unidentified cryptophyte), and perch blood cells at single prey concentrations. These prey species were shown to be consumed by $P$. piscicida in Expt 1.

One day before initiation of Expt 2, a dense culture (ca. 10000 cells $\mathrm{ml}^{-1}$ ) of Pfiesteria piscicida (strain PPIC0507) growing on Amphidinium carterae (20 000 to 30000 cells ml-1) was transferred into a $500 \mathrm{ml} \mathrm{PC}$ bottle, and cells were then starved to minimize possible residual growth. The abundances of $P$. piscicida and its prey were determined by enumerating the cells present in three $1 \mathrm{ml}$ SRCs. 
Initial concentrations of Pfiesteria piscicida and each target prey were established using an autopipette to deliver predetermined volumes of known cell concentrations into the bottles. Triplicate $42 \mathrm{ml}$ PC experiment bottles (containing mixtures of predator and prey) and triplicate control bottles (containing prey only) were set up for each predator-prey combination. Triplicate control bottles containing only P. piscicida were also established at 1 predator concentration. To ensure similar water conditions, water from predator cultures was filtered through a $0.7 \mu \mathrm{m} \mathrm{GF} / \mathrm{F}$ filter, and the same volume was added to prey control bottles as that added to experiment bottles for each predator-prey combination. Next, $10 \mathrm{ml}$ of f/2 medium was added to all bottles, which were then filled to capacity with freshly filtered seawater and capped. To determine actual predator and prey concentrations at the beginning of the experiment and after $1 \mathrm{~d}$ (perch blood cells) or $2 \mathrm{~d}$ (algal prey) of incubation, a $5 \mathrm{ml}$ aliquot was removed from each bottle and fixed with $5 \%$ Lugol's solution, and all or $>200$ predator and prey cells in three $1 \mathrm{ml}$ SRCs were enumerated. Prior to taking subsamples, the condition of $P$. piscicida and prey was assessed under a dissecting microscope. The bottles were filled again to capacity with freshly filtered seawater, capped, and placed on a rotating wheel at $0.9 \mathrm{rpm}$ at $20^{\circ} \mathrm{C}$ under an illumination of $20 \mu \mathrm{E} \mathrm{m} \mathrm{m}^{-2} \mathrm{~s}^{-1}$ provided by cool white fluorescent light on a 14:10 h light:dark cycle. Dilution of cultures that resulted from the refilling of bottles was considered when calculating growth and ingestion rates.

The specific growth rate $\left(\mu, \mathrm{d}^{-1}\right)$ of Pfiesteria piscicida was calculated as:

$$
\mu=\frac{\ln \left(L_{t} / L_{0}\right)}{t}
$$

where $L_{0}=$ initial concentration of Pfiesteria piscicida, and $L_{t}=$ final concentration after time $t(t=1 \mathrm{~d}$ for perch blood cells; 2 d for algal prey). Approximately $20 \%$ of blood cells were observed to shrink after $1 \mathrm{~d}$.

The ingestion and clearance rates were calculated using the equations of Frost (1972) and Heinbokel (1978). Incubation times for the calculation ingestion and clearance rates were the same as those for estimation of growth rate.

Expt 3-Effects of prey concentration. Expt 3 was designed to measure the growth, ingestion, and clearance rates of Pfiesteria piscicida (strain PPIC0507) as a function of prey concentration when fed Amphidinium carterae, Heterosigma akashiwo, Rhodomonas salina, an unidentified cryptophyte, and perch blood cells. We chose $A$. carterae, H. akashiwo, and the unidentified cryptophyte as prey species because they were the dominant algal species when $P$. piscicida and PLDs were abundant in coastal waters off Masan, Busan, and Yeosu in 2004-05. We also chose R. salina because Rhodomonas sp. was previously identified to be an optimal prey for P. piscicida (Parrow et al. 2001, Lin et al. 2004), and perch blood cells because (1) they were observed to support maximum growth of $P$. piscicida in our preliminary test and (2) perch is one of the most common commercial fish cultivated in the coastal waters of Korea.

One day before each experiment with target prey species was started, a dense culture (ca. 10000 cells $\mathrm{ml}^{-1}$ ) of Pfiesteria piscicida growing on prey species was transferred into two $500 \mathrm{ml} \mathrm{PC}$ bottles containing low (for 3 to 4 lower prey concentrations in Expt 3) and medium concentrations (for 4 to 5 medium and higher prey concentrations) of the same prey species. This was done to maximize any possible residual growth resulting from ingestion of prey during batch culture. The maintaining concentration of each prey, and its concentrations in the low and medium treatments, are as follows. Perch blood cells: ca. 300000 cells ml $^{-1}$, low 10000 cells ml $\mathrm{ml}^{-1}$, medium 50000 cells ml $^{-1}$; Amphidinium carterae: ca. 20000 to 30000 cells ml$^{-1}$, low 500 cells ml ${ }^{-1}$, medium 5000 cells ml $^{-1}$; Rhodomonas salina: ca. 40000 to 50000 cells $\mathrm{ml}^{-1}$, low 500 cells $\mathrm{ml}^{-1}$, medium 6000 cells $\mathrm{ml}^{-1}$; Heterosigma akashiwo: ca. 20000 to 30000 cells ml $\mathrm{m}^{-1}$, low 500 cells ml $^{-1}$, medium 5000 cells $\mathrm{ml}^{-1}$; unidentified cryptophyte: ca. 70000 to 90000 cells ml $^{-1}$, low 500 cells ml ${ }^{-1}$, medium 4000 cells $\mathrm{ml}^{-1}$. All experiments were initiated when prey cells were not detectable in ambient waters. The abundances of $P$. piscicida and its target prey were determined by enumerating the cells present in three $1 \mathrm{ml}$ SRCs.

Expt 3 was set up in the same manner as Expt 2. The range of mean actual prey (and predator) concentrations $( \pm \mathrm{SE}, \mathrm{n}=3)$ in the experimental bottles at the beginning of the experiment were 430 (3) to 896660 (29370) cells ml ${ }^{-1}$ [and 13 (0.3) to 160 (2.3) cells ml ${ }^{-1}$ ] for the blood cell, 90 (5) to 45740 (770) cells ml ${ }^{-1}$ [and 16 (0.3) to 160 (3.8)] for Amphidinium carterae, 90 (5) to 45740 (270) cells $\mathrm{ml}^{-1}$ [and 13 (1) to 180 (9)] for Rhodomonas salina, 90 (2) to 30140 (1010) cells ml ${ }^{-1}$ [and 15 (1) to 190 (2)] for Heterosigma akashiwo, and 340 (42) to 126780 (5270) cells ml ${ }^{-1}$ [and 14 (3) to 150 (3)] for a cryptophyte. The actual predator concentration in the control bottles containing only Pfiesteria piscicida for all these experiments was 140 to 170 cells $\mathrm{ml}^{-1}$. Bottles were incubated as in Expt 2.

Growth rate, $\mu$, and ingestion rates of Pfiesteria piscicida when fed each target prey were calculated as in Expt 2. Data for the growth rate of $P$. piscicida were fitted to the Michaelis-Menten equation:

$$
\mu=\frac{\mu_{\max }\left(x-x^{\prime}\right)}{K_{\mathrm{GR}}+\left(x-x^{\prime}\right)}
$$


where $\mu_{\max }=$ maximum growth rate $\left(\mathrm{d}^{-1}\right), x=$ prey concentration (cells ml- ${ }^{-1}$ or $\mathrm{ng} \mathrm{C} \mathrm{ml}^{-1}$ ), $x^{\prime}=$ threshold prey concentration (prey concentration where $\mu=0$ ), and $K_{\mathrm{GR}}=$ prey concentration sustaining $1 / 2 \mu_{\max }$. Data were iteratively fitted to the model using DeltaGraph (Delta Point).

Ingestion and clearance rates were also calculated as in Expt 2. Ingestion rate (IR) data for Pfiesteria piscicida were fitted to a Michaelis-Menten equation:

$$
\mathrm{IR}=\frac{I_{\max } X}{K_{\mathrm{IR}}+x}
$$

where $I_{\max }=$ maximum ingestion rate (cells predator $^{-1}$ $\mathrm{d}^{-1}$ or ng C predator ${ }^{-1} \mathrm{~d}^{-1}$ ), $x=$ prey concentration (cells $\mathrm{ml}^{-1}$ or $\mathrm{ng} \mathrm{C} \mathrm{ml}{ }^{-1}$ ), and $K_{\mathrm{IR}}=$ the prey concentration sustaining $1 / 2 I_{\max }$.

Cell volume of Pfiesteria piscicida. After incubation, cell length and maximum width of $P$. piscicida preserved in $5 \%$ acid Lugol's solution $(\mathrm{n}=30$ for each prey concentration) were measured using an image analysis system on images collected with a compound microscope (Image-Pro Plus 4.5, Media Cybernetics). The shape of $P$. piscicida was estimated as an oval. The cell volume of preserved $P$. piscicida was calculated as:

$$
\text { Volume }=4 / 3 \pi[(\text { cell length }+ \text { cell width }) / 4]^{3}
$$

Gross growth efficiency. Gross growth efficiency (GGE), defined as predator biomass produced $(+)$ or lost (-) per prey biomass ingested, was calculated from estimates of carbon content per cell based on cell volume for each mean prey concentration.

Potential grazing effect. By combining field data on abundances of the predator and target prey with the ingestion rates of the predator on prey obtained in the present study, we estimated the grazing coefficients attributable to Pfiesteria piscicida on co-occurring Amphidinium spp., Heterosigma akashiwo, and cryptophytes that supported high growth of the predator in Expts 2 and 3. Measuring the abundance of P. piscicida in fixed natural samples is difficult because PLDs usually co-occur with $P$. piscicida, and distinguishing between the morphology of $P$. piscicida and PLDs is very difficult. Therefore, we assumed that (1) ingestion rates of the co-occurring algae do not vary between PLDs and P. piscicida, and (2) ingestion rates of other Amphidinium species and cryptophytes by $P$. piscicida are the same as those of $A$. carterae and the unidentified cryptophyte observed in the present study.

Data on abundances of Pfiesteria piscicida and cooccurring Amphidinium spp., Heterosigma akashiwo, and cryptophytes used in this estimate were obtained from water samples collected from coastal waters off Masan (2004-05), Busan (2005), Kwangyang (2005), and Yeosu (2005).
Grazing coefficients $\left(g, \mathrm{~h}^{-1}\right)$ were calculated as:

$$
g=\mathrm{CR} \times \mathrm{PC}
$$

where $\mathrm{CR}=$ clearance rate of a target prey by Pfiesteria piscicida at a given prey concentration ( $\mathrm{ml}$ predator $^{-1} \mathrm{~h}^{-1}$ ), and $\mathrm{PC}=$ predator concentration $\left(\right.$ cells $\mathrm{ml}^{-1}$ ). CR was calculated as:

$$
\mathrm{CR}=\mathrm{IR} / \boldsymbol{X}
$$

where IR = ingestion rate of target prey by Pfiesteria piscicida (cells ingested predator ${ }^{-1} \mathrm{~h}^{-1}$ ), and $\mathrm{x}=$ prey concentration (cells $\mathrm{ml}^{-1}$ ). CR were corrected using $Q_{10}=2.8$ (Hansen et al. 1997), because in situ water temperatures and the temperature used in the laboratory for this experiment $\left(20^{\circ} \mathrm{C}\right)$ were sometimes different.

\section{RESULTS}

\section{Morphology and gene sequence of Korean isolates of Pfiesteria piscicida}

Pfiesteria piscicida was observed in coastal waters off Busan, Incheon, Kunsan, Kwangyang, Masan, and Yeosu, Korea, in July 2005 when water temperature and salinity were 21.4 to $26.8^{\circ} \mathrm{C}$ and 11.8 to $30.4 \mathrm{psu}$, respectively (Fig. 1, Table 1).

Biflagellated cells of Korean isolates of Pfiesteria piscicida are oval and have a markedly impressed cingulum. Thin plates are arranged in a Kofoidian series of Po, cp, X, 4', 1a, 5", 6c, PC, 5s, 5"', 0p, 2" ", as in Steidinger et al. (1996). The morphology and size of $P$. piscicida isolated from waters off Busan (strain PPBS0507), Kunsan (PPKS0507), Yeosu (PPYS0507), Incheon (PPIC0507), Kwangyang (PPKY0507), and Masan (PPMS0507) were almost identical.

The ranges (and mean $\pm \mathrm{SE}, \mathrm{n}=30$ ) of cell length and width of live biflagellated cells of Pfiesteria piscicida (strain PPIC0507) satiated with Heterosigma akashiwo were 9.1 to $17.0 \mu \mathrm{m}(13.5 \pm 0.3 \mu \mathrm{m})$ and 6.4 to $14.2 \mu \mathrm{m}$ $(11.0 \pm 0.3 \mu \mathrm{m})$, respectively, whereas those of live biflagellated cells starved for $2 \mathrm{~d}(\mathrm{n}=30)$ were 5.2 to $10.1 \mu \mathrm{m}(7.7 \pm 0.2 \mu \mathrm{m})$ and 4.3 to $7.6 \mu \mathrm{m}(6.1 \pm 0.2 \mu \mathrm{m})$, respectively. The ratio of cell length to cell width of live biflagellated cells starved for $2 \mathrm{~d}$ (mean $\pm \mathrm{SE}=1.3 \pm$ 0.03 ; range $=1.1$ to $1.5 ; \mathrm{n}=30$ ) was similar to that of cells satiated with $H$. akashiwo (mean $\pm \mathrm{SE}=1.2 \pm 0.01$; range $=1.1$ to $1.4 ; \mathrm{n}=30$ ) .

The SSU, ITS 1, 5.8 S, ITS 2, and partial LSU rDNA sequences of Pfiesteria piscicida obtained from 5 independent PCRs for each isolate were identical (2540 nucleotides; Table 1). The DNA sequence of strain PPMS0507 was identical to that of USA isolates, but the DNA sequences of strains PPBS0507, 
Table 1. Pfiesteria piscicida. Strain, sampling location, water temperature $\left(T,{ }^{\circ} \mathrm{C}\right)$, salinity $(\mathrm{S}$, psu), GenBank accession number (GBAN), and nucleotides of SSU rDNA of isolates. NC: North Carolina; MA: Massachusetts; ${ }^{*}$ : nucleotide site

\begin{tabular}{|c|c|c|c|c|c|c|c|c|}
\hline Strain & Sampling location & $T$ & $\mathrm{~S}$ & GBAN & $63^{*}$ & $75^{*}$ & $78^{*}$ & Source \\
\hline PPBS0507 & Busan, Korea & 26.8 & 21.8 & AM231028 & A & $\mathrm{G}$ & A & This study \\
\hline PPKS0507 & Kunsan, Korea & 21.4 & 11.8 & AM231029 & A & $\mathrm{G}$ & A & This study \\
\hline PPYS0507 & Yeosu, Korea & 24.0 & 28.7 & AM231030 & A & $\mathrm{G}$ & A & This study \\
\hline PPIC0507 & Incheon, Korea & 24.0 & 25.4 & AM231031 & $\mathrm{A}$ & G & $\mathrm{A}$ & This study \\
\hline PPKY0507 & Kwangyang, Korea & 23.5 & 30.4 & AM231032 & $\mathrm{A}$ & G & $\mathrm{A}$ & This study \\
\hline PPMS0507 & Masan, Korea & 24.5 & 12.6 & AM231033 & $\mathrm{C}$ & G & $\mathrm{A}$ & This study \\
\hline NCSU B-125-4 & Beaufort Point, NC, USA & $28-30^{\mathrm{a}}$ & $6-8^{a}$ & AF330600 & $\mathrm{C}$ & G & $\mathrm{A}$ & Tengs et al. (2003) \\
\hline NCSU 113-4 & Neuse River, NC, USA & $27-29^{a}$ & $9-11^{\mathrm{a}}$ & AF330616 & $\mathrm{C}$ & G & $\mathrm{A}$ & Tengs et al. (2003) \\
\hline \multirow[t]{2}{*}{ CCMP 1830} & $\begin{array}{l}\text { Chicamacomico River, } \\
\text { MA, USA }\end{array}$ & $18-24^{\mathrm{a}}$ & $1-5^{\mathrm{a}}$ & AF330619 & $\mathrm{C}$ & G & A & Tengs et al. (2003) \\
\hline & Oslofjord, Norway & $5-20^{\mathrm{b}}$ & $5-28^{b}$ & AY033488 & A & $\mathrm{C}$ & G & Jakobsen et al. (2002) \\
\hline
\end{tabular}

PPIC0507, PPKS0507, PPKY0507, and PPYS0507 differed by $1 \mathrm{bp}$ (A instead of $\mathrm{C}$ at the 63rd nucleotide in SSU) (Table 1).

\section{Prey species}

Among the prey offered in the present study, Pfiesteria piscicida was able to feed on the diatom Skeletonema costatum, the cryptophytes Rhodomonas salina and an unidentified cryptophyte species, the naked mixotrophic dinoflagellates Amphidinium carterae, Akashiwo sanguinea, Cochlodinium polykrikoides, and Gymnodinium catenatum, the small thecate mixotrophic dinoflagellate Heterocapsa rotundata, the raphidophytes Chattonella ovata and Heterosigma akashiwo, the blood cells of perch and flounder, and human red blood cells, whereas it did not feed on living cells of large thecate mixotrophic dinoflagellates Prorocentrum minimum, Heterocapsa triquetra, Scrippsiella trochoidea, Alexandrium catenella, Gonyaulax polygramma, and Lingulodinium polyedrum that were of ESD > $12 \mu \mathrm{m}$ (Table 2). However, P. piscicida was able to feed on dead cells of these large thecate mixotrophic dinoflagellates.

\section{Comparison of growth and ingestion rates at single prey concentrations}

We measured the growth and ingestion rates of Pfiesteria piscicida on 9 edible prey species at single prey concentrations (Table 3). When mean prey concentrations were ca. 800 to $1700 \mathrm{ng} \mathrm{C} \mathrm{ml}^{-1}$, the specific growth rates of $P$. piscicida on Heterocapsa rotundata and Chattonella ovata ( 0.32 to $0.37 \mathrm{~d}^{-1}, \mathrm{n}=6$ ) and Cochlodinium polykrikoides, Akashiwo sanguinea, and Gymnodinium catenatum ( 0.15 to $0.17 \mathrm{~d}^{-1}, \mathrm{n}=6$ ) were significantly lower than those of $P$. piscicida on perch blood cells, Rhodomonas salina, the unidentified cryptophyte, Amphidinium carterae, and Heterosigma akashiwo (0.74 to $1.57 \mathrm{~d}^{-1}, \mathrm{n}=12 ; \mathrm{p}<0.01$, 1-tailed $t$-test) (Table 3).

The ingestion rates of Pfiesteria piscicida on Heterocapsa rotundata, Chattonella ovata, Cochlodinium polykrikoides, Akashiwo sanguinea, and Gymnodinium catenatum (0.03 to 0.19 ng C predator $^{-1} \mathrm{~d}^{-1}, \mathrm{n}=$ 15) were also significantly lower than those of $P$. piscicida on perch blood cells, Rhodomonas salina, the unidentified cryptophyte, Amphidinium carterae, and Heterosigma akashiwo (0.48 to $3.59 \mathrm{ng} \mathrm{C}$ predator $^{-1}$ $\mathrm{d}^{-1}, \mathrm{n}=12 ; \mathrm{p}<0.01,1$-tailed $t$-test) (Table 3 ).

Data from this study show that specific growth rates of Pfiesteria piscicida on 8 naked microalgae were negatively correlated with prey size $(p<0.05$, linear regression ANOVA), whereas ingestion rates showed no clear correlation with prey size ( $p>0.1)$ (Fig. 2).

\section{Effects of prey concentration}

We investigated the numerical and functional responses of Pfiesteria piscicida when fed prey species that supported a relatively high rate of growth of this predator. With increasing mean prey concentration, the specific growth rate of $P$. piscicida on each diet of perch blood cells, Rhodomonas salina, Amphidinium carterae, and Heterosigma akashiwo increased rapidly with increasing mean prey concentration before reaching saturation at mean prey concentrations of ca. 100 to $600 \mathrm{ng} \mathrm{C} \mathrm{ml}^{-1}$ (Figs. 3A-D). In contrast, that on the unidentified cryptophyte increased rapidly at prey concentrations less than ca. $1100 \mathrm{ng} \mathrm{C} \mathrm{ml} \mathrm{Cl}^{-1}$, but increased slowly at higher prey concentrations (Fig. 3E). When data were fitted to Eq. (2), the maxi- 
Table 2. Expt 1. Prey species, size (equivalent spherical diameter, ESD, $\mu \mathrm{m}$ ), and concentration (cells $\mathrm{ml}^{-1}$ ) of prey offered as food to Pfiesteria piscicida. To confirm no ingestion of some prey species, additional higher prey concentrations were provided. T: thecate; NT: non-thecate; Y: P. piscicida was observed to feed on living cells; N: P. piscicida was not observed to feed on living cells. Predator abundances for each target prey were 1000 to 5000 cells ml$^{-1}$

\begin{tabular}{|c|c|c|c|}
\hline Prey species & $\begin{array}{c}\text { Mean ESD } \\
\qquad( \pm \text { SD })\end{array}$ & $\begin{array}{c}\text { Initial prey } \\
\text { conc. }\end{array}$ & $\begin{array}{l}\text { Feeding of } \\
P \text {. piscicida }\end{array}$ \\
\hline \multicolumn{4}{|l|}{ Diatoms } \\
\hline Skeletonema costatum & $5.9(1.1)$ & 100000 & $\mathrm{Y}$ \\
\hline \multicolumn{4}{|l|}{ Cryptophytes } \\
\hline Unidentified cryptophyte (NT) & $5.6(1.5)$ & 30000 & $\mathrm{Y}$ \\
\hline Rhodomonas salina (NT) & $8.8(1.5)$ & 25000 & $\mathrm{Y}$ \\
\hline \multicolumn{4}{|l|}{ Rhaphidophytes } \\
\hline Heterosigma akashiwo (NT) & $11.5(1.9)$ & 10000 & $\mathrm{Y}$ \\
\hline Chattonella ovata (NT) & $40.0(1.6)$ & 2000 & $\mathrm{Y}$ \\
\hline \multicolumn{4}{|l|}{ Mixotrophic dinoflagellates } \\
\hline Heterocapsa rotundata $(\mathrm{T})$ & $5.8(0.4)$ & 30000 & $\mathrm{Y}$ \\
\hline Amphidinium carterae (NT) & $9.7(1.6)$ & 20000 & $\mathrm{Y}$ \\
\hline Prorocentrum minimum $(\mathrm{T})$ & $12.1(2.5)$ & $10000-20000$ & $\mathrm{~N}$ \\
\hline Heterocapsa triquetra $(\mathrm{T})$ & $15.0(4.3)$ & $10000-20000$ & $\mathrm{~N}$ \\
\hline Scrippsiella trochoidea $(\mathrm{T})$ & $22.8(2.7)$ & $10000-20000$ & $\mathrm{~N}$ \\
\hline Cochlodinium polykrikoides (NT) & $25.9(2.9)$ & 3000 & $\mathrm{Y}$ \\
\hline Prorocentrum micans (T) & $26.6(2.8)$ & $3000-5000$ & $\mathrm{~N}$ \\
\hline Akashiwo sanguinea (NT) & $30.8(3.5)$ & 1000 & $\mathrm{Y}$ \\
\hline Gonyaulax polygramma $(\mathrm{T})$ & $32.5(5.4)$ & $1000-3000$ & $\mathrm{~N}$ \\
\hline Alexandrium catenella $(\mathrm{T})$ & $32.6(2.7)$ & $1000-3000$ & $\mathrm{~N}$ \\
\hline Gymnodinium catenatum (NT) & $33.9(1.6)$ & 1500 & $\mathrm{Y}$ \\
\hline Lingulodinium polyedrum $(\mathrm{T})$ & $38.2(3.6)$ & $1000-3000$ & $\mathrm{~N}$ \\
\hline \multicolumn{4}{|l|}{ Blood cells } \\
\hline Perch (NT) & $6.1(0.5)$ & 500000 & $\mathrm{Y}$ \\
\hline Flounder (NT) & $6.0(0.5)$ & 500000 & $\mathrm{Y}$ \\
\hline Human (NT) & $4.8(0.5)$ & 500000 & $\mathrm{Y}$ \\
\hline
\end{tabular}

carterae, and Heterosigma akashiwo increased rapidly at prey concentrations less than ca. 100 to $600 \mathrm{ng} \mathrm{C} \mathrm{ml}^{-1}$, but increased slowly at higher prey concentrations (Fig. 4A-D), whereas that on the unidentified cryptophyte increased continuously (Fig. 4E). When data were fitted to Eq. (3), the maximum ingestion rate of $P$. piscicida on perch blood cells was highest (4.3 ng C predator $\left.^{-1} \mathrm{~d}^{-1}\right)$, but that of $P$. piscicida on R. salina, A. carterae, and $H$. akashiwo were similar (0.7 to $1.1 \mathrm{ng} \mathrm{C}$ predator $\left.^{-1} \mathrm{~d}^{-1}\right)$. The greatest ingestion rate value of $P$. piscicida on the unidentified cryptophyte at a given mean prey concentration was $1.1 \mathrm{ng} \mathrm{C}$ predator $^{-1} \mathrm{~d}^{-1}$.

The maximum clearance rate of Pfiesteria piscicida on perch blood cells (2.5 $\mu \mathrm{l}$ predator $^{-1} \mathrm{~h}^{-1}$ ) was highest; those on Rhodomonas salina and Amphidinium carterae (1.4 to $1.5 \mu \mathrm{l}$ predator $^{-1} \mathrm{~h}^{-1}$ ) were intermediate, and those on the unidentified cryptophyte and Heterosigma akashiwo (0.1 $\mu$ l predator $^{-1}$ $\mathrm{h}^{-1}$ ) were lowest. The maximum volumespecific clearance rate of $P$. piscicida feeding on perch blood cells was $8.6 \times$ $10^{6} \mathrm{~h}^{-1}$; those on $R$. salina or A. carterae mum specific growth rates of $P$. piscicida on perch blood cells $\left(1.74 \mathrm{~d}^{-1}\right)$ and $R$. salina $\left(1.41 \mathrm{~d}^{-1}\right)$ were highest. The maximum specific growth rates of $P$. piscicida on A. carterae, H. akashiwo, and the unidentified cryptophyte were similar $\left(1.10\right.$ to $\left.1.21 \mathrm{~d}^{-1}\right)$. The threshold prey concentration (where net growth $=0$ ) for $P$. piscicida was 2 to $74 \mathrm{ng} \mathrm{C} \mathrm{ml} \mathrm{Cl}^{-1}$.

With increasing mean prey concentration, the ingestion rates of Pfiesteria piscicida on each diet of perch blood cells, Rhodomonas salina, Amphidinium were 4.0 to $4.4 \times 10^{6} \mathrm{~h}^{-1}$, and those on the unidentified cryptophyte and $H$. akashiwo were $1.3 \times 10^{5} \mathrm{~h}^{-1}$.

\section{Cell volume}

After 24 h incubation, mean cell volume of Pfiesteria piscicida fed perch blood cells increased from 290 to $930 \mu^{3}$ with increasing mean prey concentration, whereas that of starved P. piscicida was $320 \mu^{3}$

Table 3. Pfiesteria piscicida. Comparisons of growth $\left(\mu \mathrm{R}, \mathrm{d}^{-1}\right)$ and ingestion rates (IR, ng C predator $\left.{ }^{-1} \mathrm{~d}^{-1}\right)\left(\mathrm{means}^{\mathrm{a}} \mathrm{SE}, \mathrm{n}=3\right)$ on dinoflagellate (DN), raphidophyte (RA), and cryptophyte (CR) species at single mean prey concentrations (MPC, ng $\mathrm{C} \mathrm{ml}{ }^{-1}$ )

\begin{tabular}{|lccrl|}
\hline Prey species & ESD $(\mu \mathrm{m})$ & $\mathrm{MPC}$ & $\mu \mathrm{R}$ & $\mathrm{IR}$ \\
\hline Unidentified cryptophyte (CR) & 5.6 & $970(40)$ & $0.97(0.09)$ & $0.09(0.05)$ \\
Heterocapsa rotundata (DN) & 5.8 & $1650(11)$ & $0.32(0.03)$ & $0.16(0.05)$ \\
Rhodomonas salina (CR) & 8.8 & $1740(18)$ & $1.07(0.03)$ & $0.79(0.09)$ \\
Amphidinium carterae (DN) & 9.7 & $780(63)$ & $1.05(0.05)$ & $0.75(0.13)$ \\
Heterosigma akashiwo (RA) & 11.5 & $1090(63)$ & $0.92(0.03)$ & $0.28(0.12)$ \\
Cochlodinium polykrikoides (DN) & 25.9 & $1150(74)$ & $0.16(0.02)$ & $0.03(0.02)$ \\
Akashiwo sanguinea (DN) & 30.8 & $1680(105)$ & $0.15(0.03)$ & $0.06(0.05)$ \\
Gymnodinium catenatum (DN) & 33.9 & $1590(150)$ & $0.13(0.04)$ & $0.19(0.03)$ \\
Chattonella ovata (RA) & 40.0 & $1270(99)$ & $0.37(0.01)$ & $0.14(0.04)$ \\
Control (without added prey) & & 0 & $-0.08(0.01)$ & \\
\hline
\end{tabular}



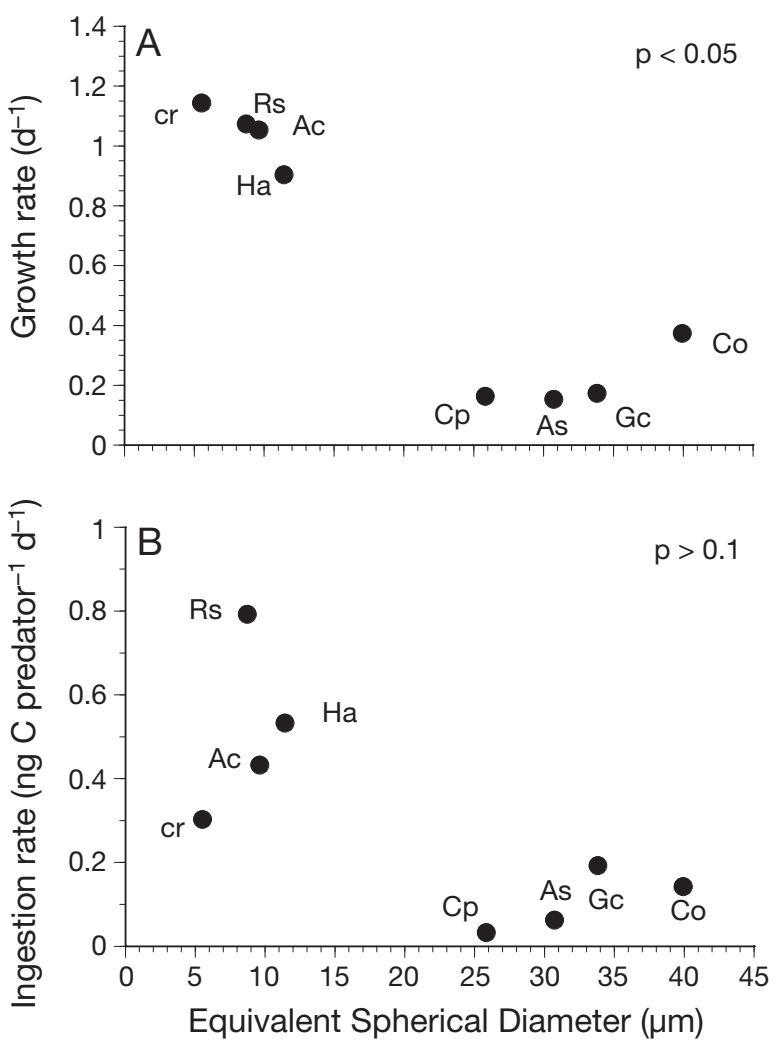

Fig. 2. Pfiesteria piscicida (strain PPIC0507). (A) Growth rates and (B) ingestion rates of 8 naked algae as a function of prey size (equivalent spherical diameter, ESD, $\mu \mathrm{m}$ ) obtained at single mean prey concentrations between ca. 800 and $1700 \mathrm{ng}$ $\mathrm{C} \mathrm{ml}^{-1}$ (Table 2); $\mathrm{p}$ values obtained from linear regression ANOVA. Ac: Amphidinium carterae; As: Akashiwo sanguinea; Co: Chattonella ovata; Cp: Cochlodinium polykrikoides; cr: unidentified cryptophyte; Gc: Gymnodinium catenatum; Ha: Heterosigma akashiwo; Rs: Rhodomonas salina

(Fig. 5A). After $48 \mathrm{~h}$ incubation, the mean cell volume of P. piscicida fed Rhodomonas salina, Amphidinium carterae, or Heterosigma akashiwo increased from $250-350$ to $910-1230 \mu^{3}$ with increasing mean prey concentration before becoming saturated, whereas those of starved $P$. piscicida were 110 to $250 \mu^{3}$ (Fig. 5B-D). However, mean cell volume of P. piscicida fed the unidentified cryptophyte did not change markedly (290 to $350 \mathrm{\mu m}^{3}$ ) with increasing mean prey concentration, and that of starved $P$. piscicida was $240 \mu^{3}$ (Fig. 5E).

\section{Gross growth efficiency}

GGE of Pfiesteria piscicida fed perch blood cells, Rhodomonas salina, Amphidinium carterae, and Heterosigma akashiwo were negative at mean prey concentrations of $\leq 4$ to $67 \mathrm{ng} \mathrm{C} \mathrm{ml}^{-1}$. However, GGE of $P$. piscicida at higher mean prey concentrations were 3 to $14 \%$ for perch blood cells, 7 to $27 \%$ for A. carterae, 23 to $62 \%$ for $H$. akashiwo, and 30 to $103 \%$ for $R$. salina.

\section{Potential grazing effect}

Grazing coefficients attributable to Pfiesteria piscicida on co-occurring Amphidinium spp. in coastal waters off Masan, Kwangyang, and Yeosu in 2004-05, when abundances of Amphidinium spp. and P. piscicida + PLDs were 1 to 16000 cells ml $^{-1}($ mean $\pm \mathrm{SE}=$ $2180 \pm 740$ cells ml$^{-1}, \mathrm{n}=35$ ) and 4 to 2560 cells ml $^{-1}$ $\left(240 \pm 80\right.$ cells ml $\left.{ }^{-1}\right)$, respectively, were 0.01 to $1.07 \mathrm{~h}^{-1}$ $\left(0.20 \pm 0.05 \mathrm{~h}^{-1}\right)$ (Fig. 6A).

Grazing coefficients attributable to Pfiesteria piscicida on co-occurring Heterosigma akashiwo in coastal waters off Masan in 2004-05, when abundances of $H$. akashiwo and P. piscicida + PLDs were 20 to 87680 cells $\mathrm{ml}^{-1}$ (mean $\pm \mathrm{SE}=12890 \pm 3740$ cells ml $\left.{ }^{-1}, \mathrm{n}=29\right)$ and 40 to 10200 cells ml $^{-1}\left(1530 \pm 440\right.$ cells ml$\left.^{-1}\right)$, respectively, were 0.01 to $0.45 \mathrm{~h}^{-1}\left(0.06 \pm 0.02 \mathrm{~h}^{-1}\right)$ (Fig. 6B).

Grazing coefficients attributable to Pfiesteria piscicida on co-occurring cryptophytes in coastal waters off Masan, Busan, Kwangyang, and Yeosu in 2004-05, when abundances of cryptophytes and P. piscicida + PLDs were 40 to 392440 cells ml $^{-1}$ (mean $\pm \mathrm{SE}=54460$ \pm 10240 cells ml${ }^{-1}, \mathrm{n}=57$ ) and 10 to 10200 cells ml ${ }^{-1}$ $\left(860 \pm 240\right.$ cells ml $\left.\mathrm{m}^{-1}\right)$, respectively, were 0.00 to $0.22 \mathrm{~h}^{-1}\left(0.03 \pm 0.01 \mathrm{~h}^{-1}\right)$ (Fig. 6C).

\section{DISCUSSION}

\section{Morphology and DNA sequences of Korean isolates of Pfiesteria piscicida}

This study showed that Pfiesteria piscicida was present in several locations along the coasts of southern and western Korea. Pfiesteria piscicida collected from Masan (strain PPMS0507) and several USA isolates may have the same origin, because their DNA sequence and morphology were identical (Table 1). However, the DNA sequences of $P$. piscicida isolated from 5 other Korean locations (strains PPBS0507, PPIC0507, PPKS0507, PPKY0507, PPYS0507) differed by $1 \mathrm{bp}$ (A instead of $\mathrm{C}$ at the 63rd nucleotide in SSU) from USA isolates (Table 1; Tengs et al. 2003). The 63rd nucleotide of these 5 Korean isolates was the same as that of the Norway isolate (Jakobsen et al. 2002), but the 75th and 78th nucleotides of these isolates ( $G$ and $A$, respectively) differed from those of the Norway isolate ( $\mathrm{C}$ and $\mathrm{G}$ ). We analyzed the sequences of $>5$ DNA copies for each isolate, and thus there is no possibility that these differences are just variants 

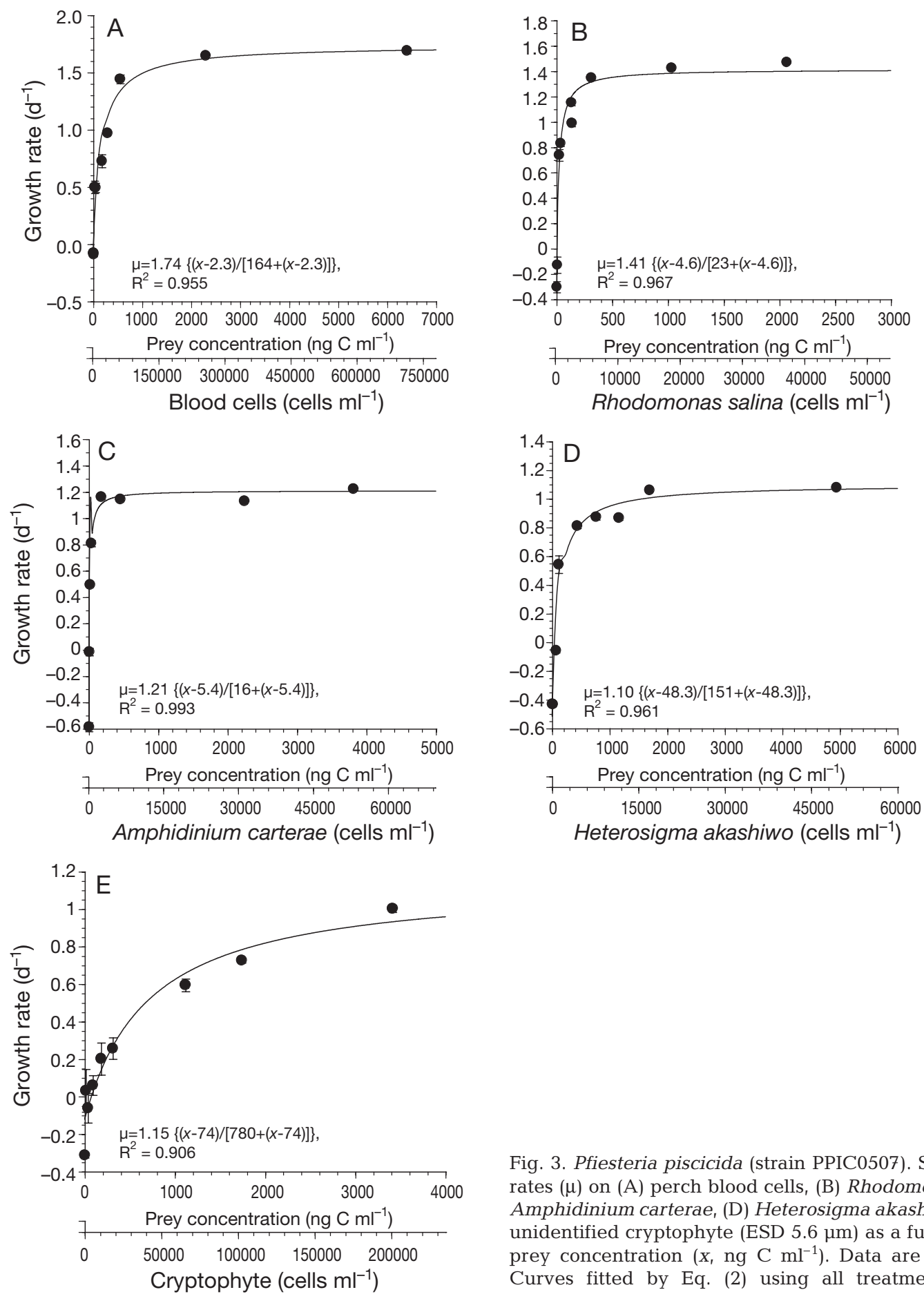

Fig. 3. Pfiesteria piscicida (strain PPIC0507). Specific growth rates $(\mu)$ on (A) perch blood cells, (B) Rhodomonas salina, (C) Amphidinium carterae, (D) Heterosigma akashiwo, and (E) an unidentified cryptophyte (ESD $5.6 \mu \mathrm{m}$ ) as a function of mean

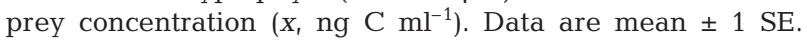
Curves fitted by Eq. (2) using all treatments in Expt 3

within the many copies of the ribosomal gene. Therefore, the DNA sequence of these 5 Korean isolates is unique and reported for the first time in the present study. However, the morphology of strain PPMS0507 and other Korean isolates was identical (Table 1). Therefore, a $1 \mathrm{bp}$ difference in the DNA sequence may not be enough to affect the morphology of $P$. pis-

cicida; nevertheless, it may be useful to understand the similarity among isolates from waters of different continents or countries, and thus the origins of each isolate.

The means of cell length and width of live Pfiesteria piscicida cells satiated with Heterosigma akashiwo (13.5 and $11.0 \mu \mathrm{m}$, respectively) were less than those of 

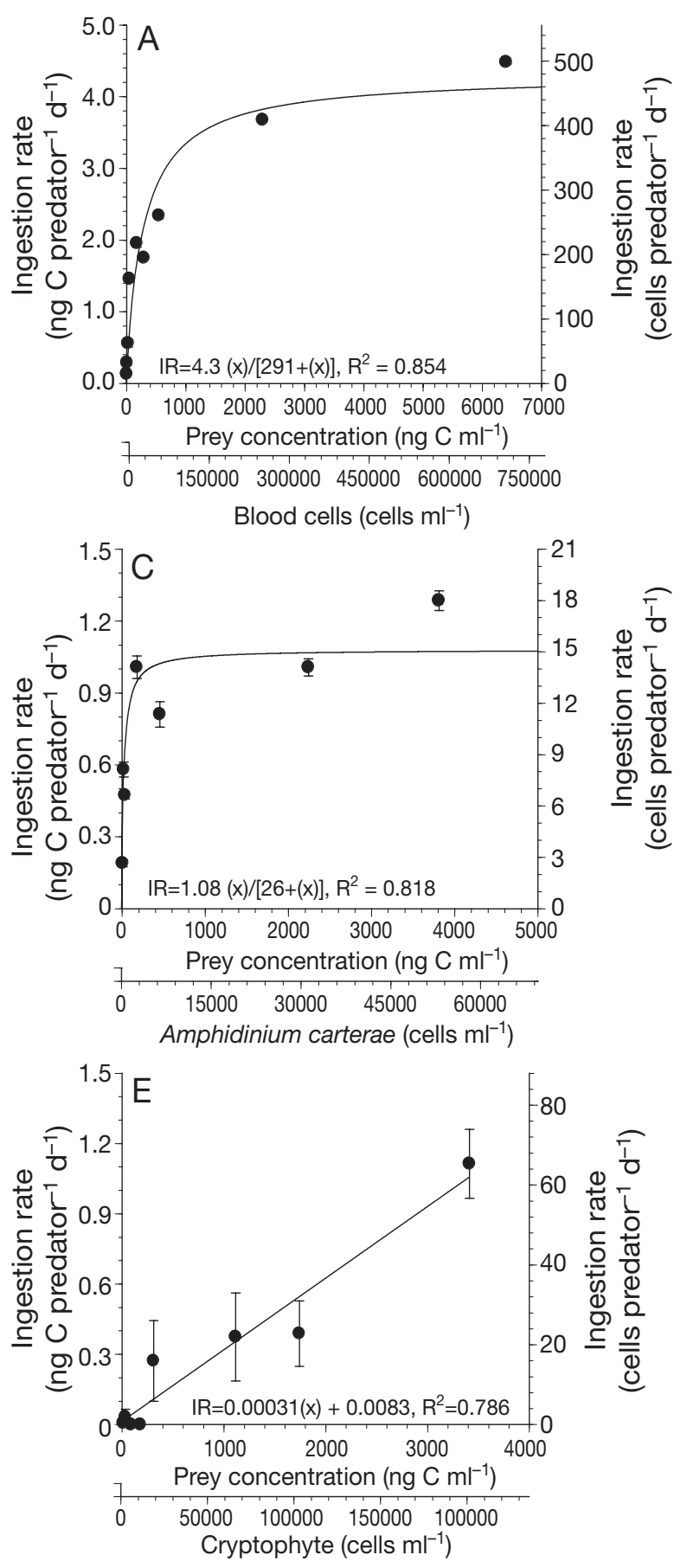

the PLD Stoeckeria algicida satiated with the same prey (16.8 and $12.9 \mu \mathrm{m}$, respectively) (Jeong et al. 2005a). However, the ranges of cell length and width of live $P$. piscicida cells satiated with $H$. akashiwo (9.1 to 17.0 and 6.4 to $14.2 \mu \mathrm{m}$, respectively) overlapped with the lower boundaries of the ranges of cell length and width of $S$. algicida satiated with $H$. akashiwo (14.4 to 20.8 and 10.0 to $17.4 \mu \mathrm{m}$, respectively) (Jeong et al. 2005a). The ratios of cell length to cell width of $P$. pisci-
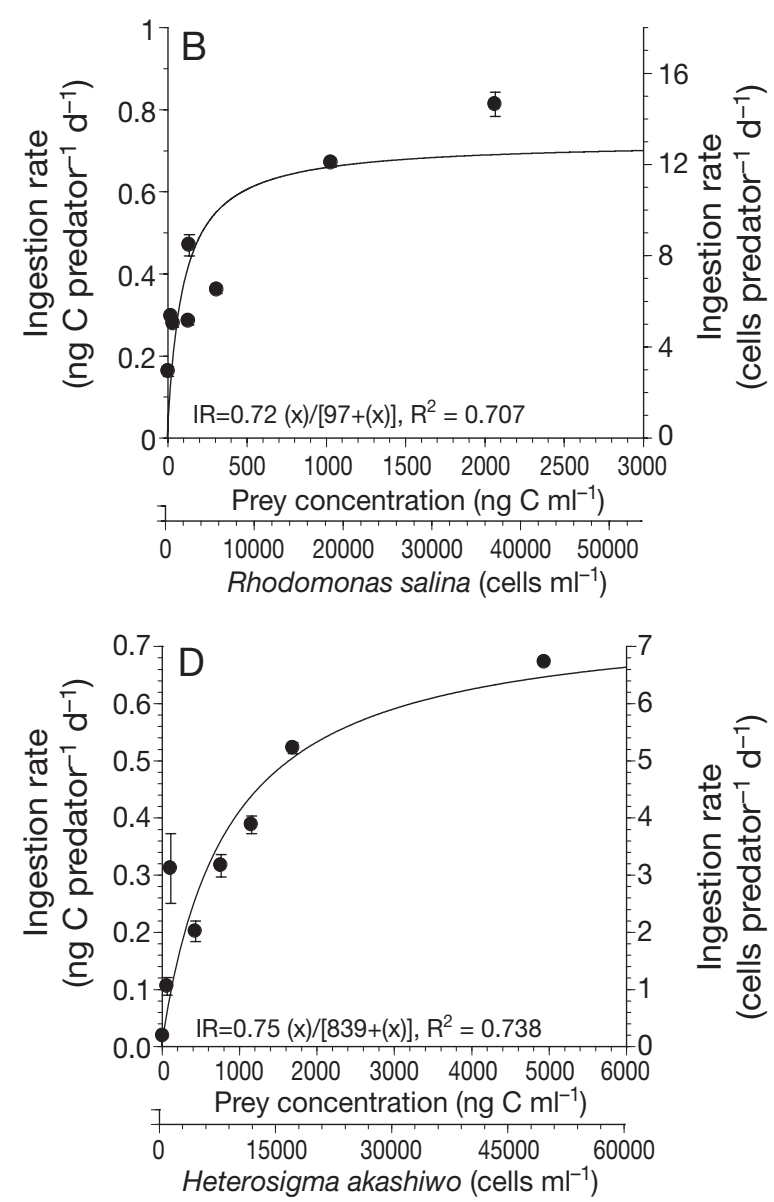

Fig. 4. Pfiesteria piscicida (strain PPIC0507). Ingestion rates (IR) of (A) perch blood cells, (B) Rhodomonas salina, (C) Amphidinium carterae, (D) Heterosigma akashiwo, and (E) an unidentified cryptophyte (ESD $5.6 \mu \mathrm{m}$ ) as a function of mean prey concentration $\left(x, \mathrm{ng} \mathrm{C} \mathrm{ml}{ }^{-1}\right)$. Data are mean $\pm 1 \mathrm{SE}$. Curves fitted by Eq. (3) (A-D) or by linear equation (E) using all treatments in Expt 3

cida satiated with $H$. akashiwo (mean $=1.2$; range $=1.0$ to 1.4 ) were similar to those of $S$. algicida $($ mean $=1.3$; range $=1.1$ to 1.6 ). Therefore, based only on morphology, it may be very difficult to completely distinguish $P$. piscicida from $S$. algicida in natural water samples collected during $H$. akashiwo blooms. Analyses of DNA sequences, DNA probes, and/or SEM or calcoflourstained images are needed to distinguish one species from the other. 


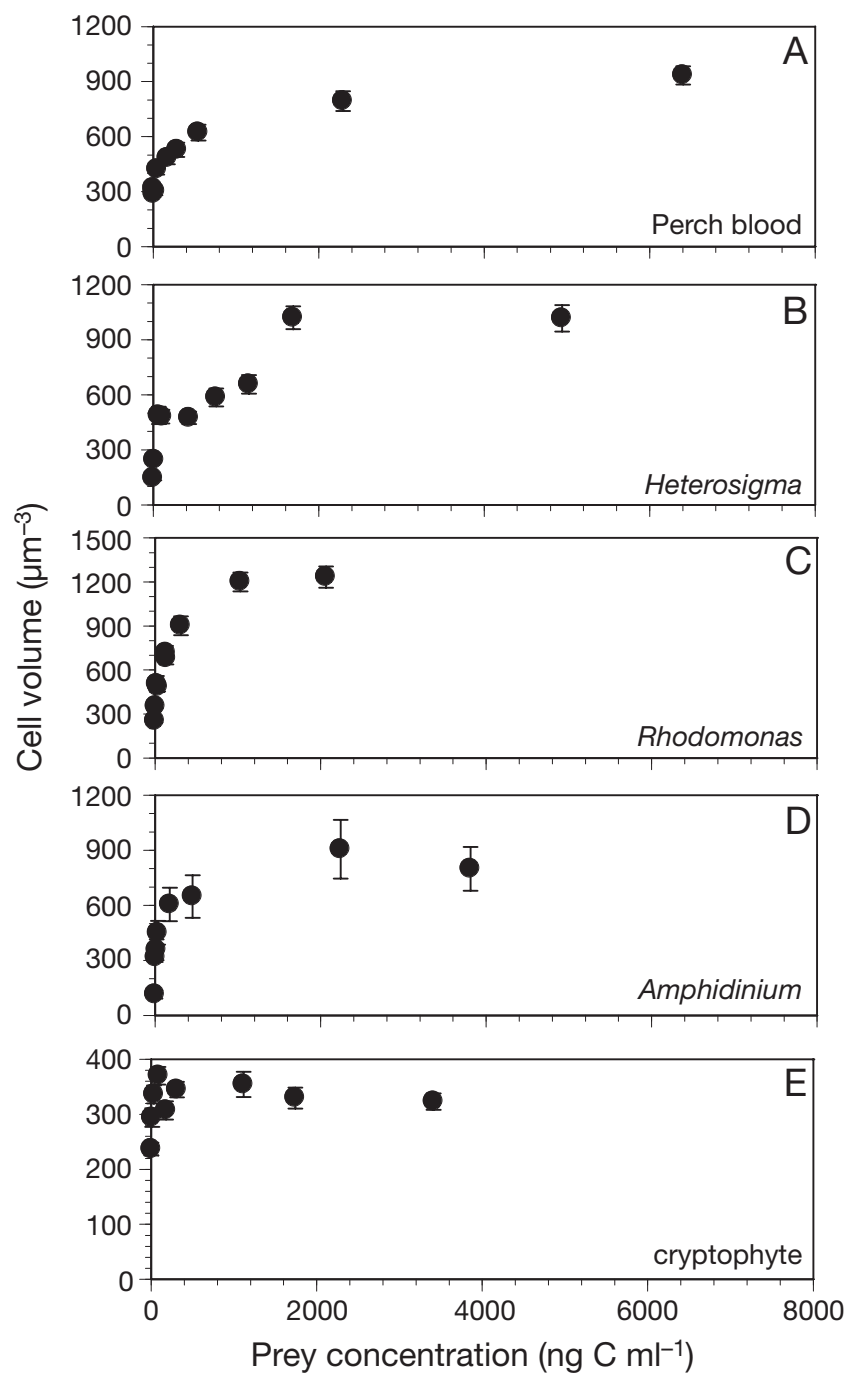

Fig. 5. Pfiesteria piscicida. Cell volume when fed (A) perch blood cells after $24 \mathrm{~h}$ incubation, and (B) Heterosigma akashiwo, (C) Rhodomonas salina, (D) Amphidinium carterae, and (E) an unidentified cryptophyte after $48 \mathrm{~h}$ incubation, as a function of mean prey concentration. Data are means $\pm 1 \mathrm{SE}$

\section{Prey species}

Before the present study, mixotrophic dinoflagellates and raphidophytes had not been tested as prey for Pfiesteria piscicida, even though there is a high probability that $P$. piscicida does consume them; many mixotrophic dinoflagellate species and/or some raphidophyte species usually co-occur with $P$. piscicida (authors' pers. obs.). This study demonstrated that $P$. piscicida was able to feed on all naked mixotrophic dinoflagellates, the smallest thecate dinoflagellate Heterocapsa rotundata, and all raphidophytes offered, but that it did not feed on large thecate dinoflagellates of ESD $>12 \mu \mathrm{m}$. The presence/absence of dinoflagellate theca may be a critical factor that affects the pre-

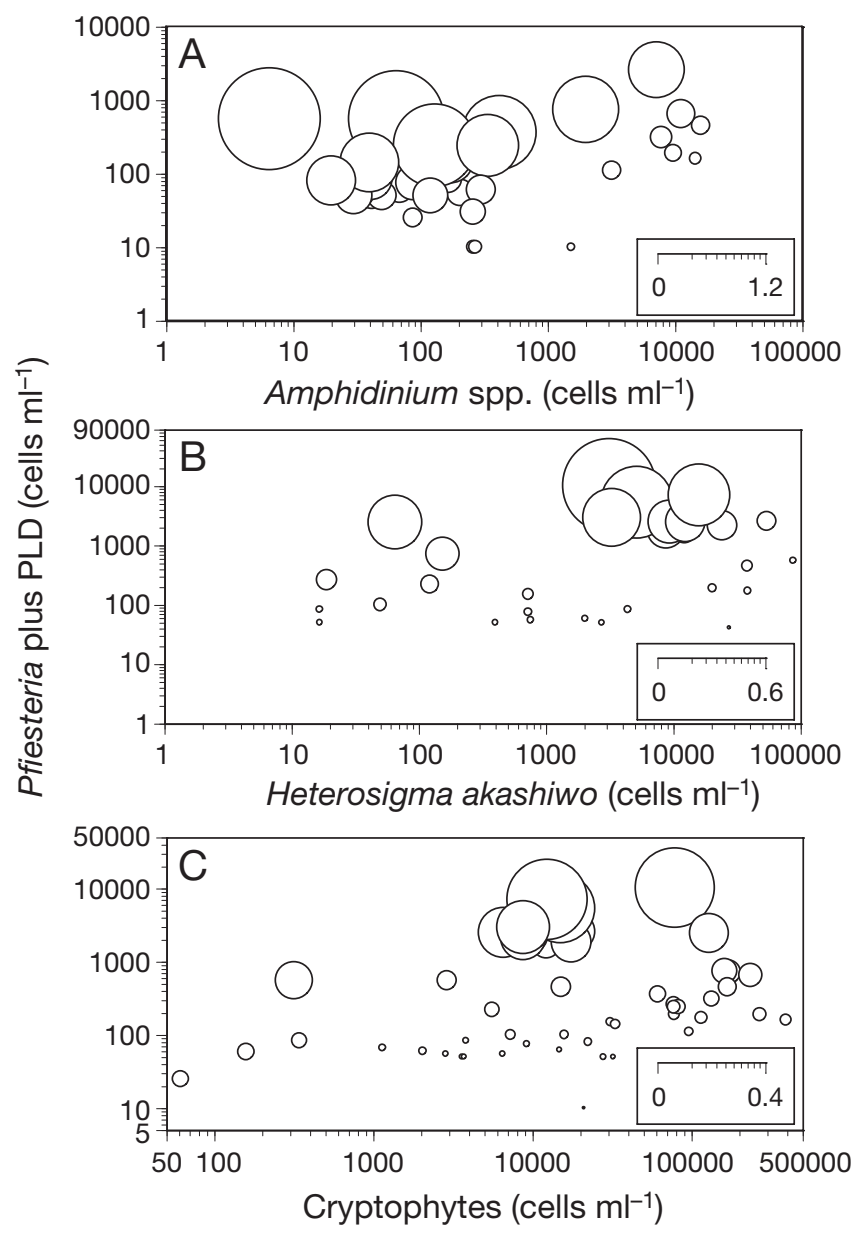

Fig. 6. Pfiesteria piscicida. Calculated grazing coefficients $(g)$ in relation to concentrations of co-occurring (A) Amphidinium spp. $(\mathrm{n}=35)$, (B) Heterosigma akashiwo $(\mathrm{n}=29)$, and $(\mathrm{C})$ cryptophytes $(\mathrm{n}=57)$. Scales in inset boxes are $g\left(\mathrm{~h}^{-1}\right)$

dation of $P$. piscicida on target prey. $P$. piscicida may have difficulties in capturing a large swimming thecate dinoflagellate cell and/or extracting materials from the prey using a peduncle. Immobility of prey cells may also be important $-P$. piscicida was able to feed on diatoms that have hard $\mathrm{SiO}_{2}$ valves and dead cells of large thecate mixotrophic dinoflagellates. These findings suggest that $P$. piscicida may grow favorably under conditions when naked dinoflagellates, raphidophyte, and/or cryptophytes are abundant, or during the declining stage of blooms of large thecate dinoflagellates.

\section{Growth and ingestion}

The results of the present study show that the growth of Pfiesteria piscicida was affected by the kind of prey and prey concentration, with highest growth rates on 
small naked algae Amphidinium carterae and Heterosigma akashiwo, relatively low growth on large naked algae Akashiwo sanguinea, Chattonella ovata, Cochlodinium polykrikoides, and/or Gymnodinium catenatum, and no growth on large thecate mixotrophic dinoflagellates Prorocentrum minimum, Heterocapsa triquetra, Scrippsiella trochoidea, Gonyaulax polygramma, Alexandrium catanella, and Lingulodinium polyedrum. Therefore, blooms dominated by small naked algae may be indicative of conditions that favor the presence of $P$. piscicida.

The growth rates of Pfiesteria piscicida on 8 naked algae were significantly negatively correlated with the prey size, whereas ingestion rates showed no clear correlation with prey size. Pfiesteria piscicida might spend more energy when capturing, handling, and extracting materials from larger prey species using a peduncle than from smaller prey species, because the energy obtained from larger and smaller prey were not significantly different.

The observed maximum growth rate $\left(\mu_{\max }\right)$ of Korean isolate PPIC0507 fed Rhodomonas salina (mean $\pm \mathrm{SE}=$ $1.47 \pm 0.01 \mathrm{~d}^{-1}$, observed $\mu_{\max } ; 1.41 \mathrm{~d}^{-1}, \mu_{\max }$ obtained from Eq. 2) determined in the present study was very similar to that of USA isolate NCSU 113-3 fed Rhodomonas sp. $\left(1.5 \mathrm{~d}^{-1}\right.$, observed $\mu_{\max } 1.76 \mathrm{~d}^{-1}, \mu_{\max }$ obtained using Monad functions; Lin et al. 2004), previously known as the optimal prey for P. piscicida. The $\mu_{\max }$ of 2 other USA isolates (Parrow et al. 2001) fed Rhodomonas sp. were also similar to that of the Korean isolate PPIC0507. Therefore, the Korean and USA isolates have similar growth rates when fed Rhodomonas spp., in addition to similar DNA sequences and morphology.

In the present study, the $\mu_{\max }$ of Pfiesteria piscicida fed perch blood cells (mean $\pm \mathrm{SE}=1.69 \pm 0.03 \mathrm{~d}^{-1}$, observed $\mu_{\max } i 1.74 \mathrm{~d}^{-1}, \mu_{\max }$ obtained from Eq. 2) was greater than that when fed Rhodomonas salina. Therefore, it appears that, among the prey tested in the present study, perch blood cells were optimal for P. piscicida. Flounder blood cells also supported high growth of $P$. piscicida in our preliminary test. Due to the dense population of fish maintained in a cage, the fish make a lot of gashes on each other; thus, $P$. piscicida may enter these gashes and suck blood cells of the fishes, which may cause illness or death of the fish (Burkholder et al. 2001a, Glasgow et al. 2001).

The $\mu_{\max }$ of Pfiesteria piscicida on Amphidinium carterae $\left(1.21 \mathrm{~d}^{-1}\right)$ was slightly higher than that of the heterotrophic dinoflagellate Oxyrrhis marina on the same prey $\left(1.17 \mathrm{~d}^{-1}\right)$, Jeong et al. 2001a), but much higher than that of another heterotrophic dinoflagellate, Polykrikos kofoidii $\left(0.10 \mathrm{~d}^{-1}\right)$ or the ciliates Tiarina fusus $\left(-0.04 \mathrm{~d}^{-1}\right)$ and Strombidinopsis sp. $\left(<0 \mathrm{~d}^{-1}\right.$; Jeong et al. $1999,2001 \mathrm{~b}, 2002)$. Therefore, $P$. piscicida is expected to be one of the dominant heterotrophic protists with $O$. marina during the red tides dominated by A. carterae.

The $\mu_{\max }$ of Pfiesteria piscicida when fed Heterosigma akashiwo $\left(1.10 \mathrm{~d}^{-1}\right)$ was lower than that of heterotrophic dinoflagellates Stoeckeria algicida $\left(1.63 \mathrm{~d}^{-1}\right.$, Jeong et al. 2005b) or Oxyrrhis marina when fed the same prey (1.43 $\mathrm{d}^{-1}$; Jeong et al. 2003). Nevertheless, a $\mu_{\max }$ of $1.10 \mathrm{~d}^{-1}$ is still high. Therefore, we expect high abundances of mixed populations of $P$. piscicida, $S$. algicida, and $O$. marina during blooms dominated by H. akashiwo, whereas species with lower growth rates such as the heterotrophic dinoflagellate Gyrodinium dominans or ciliate Tiarina fusus ( $\mu_{\max }: 0.12$ to $0.15 \mathrm{~d}^{-1}$ ) may not be able to compete and thus will be less abundant (Nakamura et al. 1995, Jeong et al. 2002).

The highest maximum ingestion rate $\left(I_{\max }\right)$ of Pfiesteria piscicida observed in the present study (4.3 ng C predator $^{-1} \mathrm{~d}^{-1}$ ), obtained when perch blood cells were provided as food, was much higher than $I_{\max }$ when algal prey was provided (0.7 to $1.1 \mathrm{ng}$ C predator ${ }^{-1} \mathrm{~d}^{-1}$ ). The liquid materials of perch blood cells were observed to be easily transferred into the body of $P$. piscicida through a peduncle. The $I_{\max }$ of $P$. piscicida fed perch blood cells (ca. 480 cells predator ${ }^{-1} \mathrm{~d}^{-1}$ ) was much higher than that when fed tilapia blood cells (220 cells predator ${ }^{-1} \mathrm{~d}^{-1}$, no available carbon-base unit; Glasgow et al. 1998). Therefore, ingestion rates of $P$. piscicida when fed blood cells of different fish species may differ; thus, it would be worthwhile to measure ingestion rates when blood cells of other fish species are provided, so that such comparisons can be made in the future. The highest $I_{\max }$ of $P$. piscicida obtained in the present study is also much higher than that of PLD Stoeckeria algicida (0.8 ng C predator ${ }^{-1} \mathrm{~d}^{-1}$; Jeong et al. 2005b). In our preliminary test, the $I_{\max }$ of $S$. algicida was low when fed perch blood cells (ca. $0.4 \mathrm{ng} \mathrm{C}$ predator $^{-1} \mathrm{~d}^{-1}$ ). Therefore, the ability of $P$. piscicida to feed on blood cells accounts for its high $I_{\max }$ in comparison with that of $S$. algicida.

The $I_{\max }$ of Pfiesteria piscicida when fed the unidentified cryptophyte (1.1 ng C predator ${ }^{-1} \mathrm{~d}^{-1}$ ) was much higher than those of the mixotrophic dinoflagellates Cochlodinium polykrikoides, Gonyaulax polygramma, Heterocapsa triquetra, Prorocentrum donghaiense, or Prorocentrum micans when fed the same prey (0.03 to $0.18 \mathrm{ng}$ C predator ${ }^{-1} \mathrm{~d}^{-1}$; Jeong et al. 2004a, 2005c,d). According to our field data, the maximum abundances of $P$. piscicida (combined with PLDs) in Korean waters were ca. 10000 to 20000 cells ml $\mathrm{ml}^{-1}$, while those of $C$. polykrikoides, G. polygramma, or $H$. triquetra were 20000 to 30000 cells $\mathrm{ml}^{-1}$. If the abundances of $P$. piscicida and these mixotrophic dinoflagellates are similar at a given time, the unidentified cryptophyte will be removed by $P$. piscicida at a much greater rate than by the mixotrophic dinoflagellates. 
The maximum GGE of Pfiesteria piscicida fed Amphidinium carterae (27\%) was observed to be similar to those of heterotrophic dinoflagellates fed algae (Jeong \& Latz 1994, Naustvoll 1998, Kim \& Jeong 2004). However, GGE of $P$. piscicida fed perch blood cells were distinctly low (3 to $14 \%$ ). Perch blood cells might not be nutritious prey for $P$. piscicida. GGEs of $P$. piscicida fed Heterosigma akashiwo and Rhodomonas salina were high (23 to 62 and 30 to $103 \%$, respectively). The kleptoplastids from $R$. salina and $H$. akashiwo may support mixotrophic growth of P. piscicida, as reported by Lewitus et al. (1999).

\section{Potential grazing effect}

In our estimation of grazing coefficients attributable to Pfiesteria piscicida (+PLDs) on co-occurring algal prey, $P$. piscicida (+PLDs) removed 0.6 to $66 \%$ (mean \pm $\mathrm{SE}=15 \pm 3 \%$ ) of populations of co-occurring Amphidinium spp. in $1 \mathrm{~h}$. In addition, $P$. piscicida (+PLDs) removed 0.1 to $36 \%$ (mean $\pm \mathrm{SE}=5 \pm 2 \%$ ) of populations of co-occurring Heterosigma akashiwo and 0.02 to $20 \%$ (mean $\pm \mathrm{SE}=2 \pm 1 \%$ ) of cryptophytes in $1 \mathrm{~h}$. Therefore, grazing by P. piscicida (+PLDs) may sometimes have a considerable effect on populations of Amphidinium spp., H. akashiwo, or cryptophytes. However, in the present study, our estimation of grazing coefficients attributable to $P$. piscicida on co-occurring algal prey was limited by our inability to distinguish this dinoflagellate from PLDs. For better estimation of the effect of grazing of $P$. piscicida and PLDs on algal prey, it would be worthwhile to measure the ingestion rates of other PLDs as a function of prey concentration.

The maximum abundances of Pfiesteria piscicida and PLDs in natural environments are ca. 10000 to 25000 cells ml ${ }^{-1}$ (e.g. Glasgow et al. 2001, Jeong et al. 2005b), whereas those of other heterotrophic dinoflagellates such as Oxyrrhis marina, Polykrikos spp. Gyrodinium spp., and Protoperidinium spp. are 100 to 2000 cells ml ${ }^{-1}$ (Lessard 1984, Jacobson 1987, Jeong 1995, 1999, Jeong et al. 2001b, Sherr \& Sherr 2002, Jeong et al. 2004b). The effects of $P$. piscicida and PLD grazing on blooms of the small naked algae tested in the present study may be greater than those of other heterotrophic dinoflagellates, because rates of ingestion by $P$. piscicida on some of these algae were comparable to those by other heterotrophic dinoflagellates on the same prey. Widespread distribution of $P$. piscicida in Korean waters and the ability of $P$. piscicida to graze on mixotrophic dinoflagellates, raphidophytes, and cryptophytes implies that $P$. piscicida may play important roles in dynamics of blooms dominated by these algal prey.
Acknowledgements. We thank Seong Taek Kim, Jae Yoon Song, Kyeong Ah Seong, Dong Hyun Kim, Seung Hyun Lee, Myung Ok Park, Jeong Eun Song, and Soo Kyeom Kim for sampling and technical support. This study was funded by a Sooteuk grant from MOMAF \& KMI and a NRL grant from MOST \& KOSEF (M1-0500-00-0174).

\section{LITERATURE CITTED}

Burkholder JM, Glasgow HB Jr (1995) Interactions of a toxic estuarine dinoflagellate with microbial predators and prey. Arch Protistenkd 145:177-188

Burkholder JM, Glasgow HB Jr (1997) Trophic controls on stage transformations of a toxic ambush-predator dinoflagellate. J Eukaryot Microbiol 44:200-205

Burkholder JM, Noga EJ, Hobbs CW, Glasgow HB Jr, Smith SA (1992) New 'phantom' dinoflagellate is the causative agent of major estuarine fish kills. Nature 358:407-410

Burkholder JM, Glasgow HB, Deamer-Melia N (2001a) Overview and present status of the toxic Pfiesteria complex. Phycologia 40:186-214

Burkholder JM, Glasgow HB, Deamer-Melia NJ, Springer J, Parrow MW, Zhang C, Cancellieri PJ (2001b) Species of the toxic Pfiesteria complex, and the importance of functional type in data interpretation. Environ Health Perspect 109:667-679

Feinstein TN, Traslavina R, Sun M, Lin S (2002) Effects of light on photosynthesis, grazing, and population dynamics of the heterotrophic dinoflagellate Pfiesteria piscicida (Dinophyceae). J Phycol 38:659-669

Frost BW (1972) Effects of size and concentration of food particles on the feeding behavior of the marine planktonic copepod Calanus pacificus. Limnol Oceanogr 17:805-815

Glasgow HB, Lewitus AJ, Burkholder JM (1998) Feeding behavior of the ichthyotoxic estuarine dinoflagellate, Pfiesteria piscicida, on amino acids, algal prey, and fish vs. mammalian erythrocytes. In: Reguera B, Blanco J, Fernandez ML, Wyatt T (eds) Harmful microalgae. Intergovernmental Oceanographic Commission of UNESCO, Paris, p 394-397

Glasgow HB, Burkholder JM, Mallin MA, Deamer-Melia NJ, Reed RE (2001) Field ecology of toxic Pfiesteria complex species and a conservative analysis of their role in estuarine fish kills. Environ Health Perspect 109:715-730

Gransden SG, Lewitus AJ (2003) Grazing of two euplotid ciliates on the heterotrophic dinoflagellates Pfiesteria piscicida and Cryptoperidiniopsis sp. Aquat Microb Ecol 33: 303-308

Guillard RRL, Ryther JH (1962) Studies of marine planktonic diatoms. I. Cyclotella nana Hustedt and Detonula confervacea (Cleve) Grun. Can J Microbiol 8:229-239

Hansen PJ, Bjornsen PK, Hansen BW (1997) Zooplankton grazing and growth: scaling within the $2-2000-\mu \mathrm{m}$ body size range. Limnol Oceanogr 42:687-704

Heinbokel JF (1978) Studies on the functional role of tintinnids in the Southern California Bight. I. Grazing and growth rates in laboratory cultures. Mar Biol 47:177-189

Jacobson DM (1987) The ecology and feeding biology of thecate heterotrophic dinoflagellates. PhD thesis, Woods Hole Oceanographic Institution/Massachusetts Institute of Technology

Jakobsen KS, Tengs T, Vatne A, Bowers HA and 5 others (2002) Discovery of the toxic dinoflagellate Pfiesteria in northern European waters. Proc R Soc Lond B 269: 211-214

Jeong HJ (1995) The interactions between microzooplank- 
tonic grazers and dinoflagellates causing red tides in the open coastal waters off southern California. $\mathrm{PhD}$ dissertation, University of California, San Diego, CA

Jeong HJ (1999) The ecological roles of heterotrophic dinoflagellates in marine planktonic community. J Eukaryot Microbiol 46:390-396

Jeong HJ, Latz MI (1994) Growth and grazing rates of the heterotrophic dinoflagellate Protoperidinium spp. on red tide dinoflagellates. Mar Ecol Prog Ser 106:173-185

Jeong HJ, Shim JH, Lee CW, Kim JS, Koh SM (1999) Growth and grazing rates of the marine planktonic ciliate Strombidinopsis sp. on red-tide and toxic dinoflagellates. J Eukaryot Microbiol 46:69-76

Jeong HJ, Kang HJ, Shim JS, Park JY, Kim JS, Song JY, Choi HJ (2001a) Interactions among the toxic dinoflagellate Amphidinium carterae, the heterotrophic dinoflagellate Oxyrrhis marina, and the calanoid copepods Acartia spp. Mar Ecol Prog Ser 218:77-86

Jeong HJ, Kim SK, Kim JS, Kim ST, Yoo YD, Yoon JY (2001b) Growth and grazing rates of the heterotrophic dinoflagellate Polykrikos kofoidii on red-tide and toxic dinoflagellates. J Eukaryot Microbiol 48:298-308

Jeong HJ, Yoon JY, Kim JS, Yoo YD, Seong KA (2002) Growth and grazing rates of the prostomatid ciliate Tiarina fusus on red-tide and toxic algae. Aquat Microb Ecol 28: 289-297

Jeong HJ, Kim JS, Yoo YD, Kim ST and 6 others (2003) Feeding by the heterotrophic dinoflagellate Oxyrrhis marina on the red-tide raphidophyte Heterosigma akashiwo: a potential biological method to control red tides using mass-cultured grazers. J Eukaryot Microbiol 50:274-282

Jeong HJ, Yoo YD, Kim JS, Kim TH, Kim JH, Kang NS, Yih WH (2004a) Mixotrophy in the phototrophic harmful alga Cochlodinium polykrikoides (Dinophycean): prey species, the effects of prey concentration and grazing impact. J Eukaryot Microbiol 51:563-569

Jeong HJ, Yoo YD, Kim ST, Kang NS (2004b) Feeding by the heterotrophic dinoflagellate Protoperidinium bipes on the diatom Skeletonema costatum. Aquat Microb Ecol 36: 171-179

Jeong HJ, Kim JS, Park JY, Kim JH and 5 others (2005a) Stoeckeria algicida n. gen., n. sp. (Dinophyceae) from the coastal waters off southern korea: morphology and small subunit ribosomal DNA gene sequence. J Eukaryot Microbiol 52:382-390

Jeong HJ, Kim JS, Kim JH, Kim ST, Seong KA, Kim TH, Song JY, Kim SK (2005b) Feeding and grazing impact by the newly described heterotrophic dinoflagellate Stoeckeria algicida on the harmful alga Heterosigma akashiwo. Mar Ecol Prog Ser 295:69-78

Jeong HJ, Yoo YD, Park JY, Song JY, Kim ST, Lee SH, Kim KY, Yih WH (2005c) Feeding by the phototrophic red-tide dinoflagellates: five species newly revealed and six species previously known to be mixotrophic. Aquat Microb Ecol 40:133-155

Jeong HJ, Yoo YD, Seong KA, Kim JH and 5 others (2005d) Feeding by the mixotrophic dinoflagellate Gonyaulax polygramma: mechanisms, prey species, the effects of prey concentration, and grazing impact. Aquat Microb Ecol 38:249-257

Kamiyama T, Arima S (2001) Feeding characteristics of two tintinnid ciliate species on phytoplankton including harmful species: effects of prey size on ingestion rates and selectivity. J Exp Mar Biol Ecol 257:281-296

Kim JS, Jeong HJ (2004) Feeding by the heterotrophic dinoflagellates Gyrodinium dominans and G. spirale on the red-tide dinoflagellate Prorocentrum minimum. Mar
Ecol Prog Ser 280:85-94

Lessard EJ (1984) Oceanic heterotrophic dinoflagellates: distribution, abundance and role as microzooplankton. $\mathrm{PhD}$ dissertation, University of Rhode Island

Lewitus AJ, Glasgow HB Jr, Burkholder JAM (1999) Kleptoplastidy in the toxic dinoflagellate Pfiesteria piscicida (Dinophyceae). J Phycol 35:303-312

Lewitus AJ, Hayes KC, Willis BM, Burkholder JM and 5 others (2002) Low abundance of the dinoflagellates, Pfiesteria piscicida, P. shumwayae, and Cryptoperidiniopsis spp., in South Carolina tidal creeks and open estuaries. Estuaries 25:586-597

Lin S, Mulholland MR, Zhang H, Feinstein TN, Jochem FJ, Carpenter EJ (2004) Intense grazing and prey-dependent growth of Pfiesteria piscicida (Dinophyceae). J Phycol 40: 1062-1073

Litaker RW, Vandersea MW, Kibler SR, Reece KS and 6 others (2003) Identification of Pfiesteria piscicida (Dinophyceae) and Pfiesteria-like organisms using internal transcribed spacer-specific PCR assays. J Phycol 39:754-761

Menden-Deuer S, Lessard E (2000) Carbon to volume relationships for dinoflagellates, diatoms, and other protist plankton. Limnol Oceanogr 45:569-579

Nakamura Y, Suzuki S, Hiromi J (1995) Growth and grazing of a naked heterotrophic dinoflagellate, Gyrodinium dominans. Aquat Microb Ecol 9:157-164

Naustvoll LJ (1998) Growth and grazing by the thecate heterotrophic dinoflagellate Diplopsalis lenticula (Diplopsalidaceae, Dinophyceae). Phycologia 37:1-9

Parrow MW, Glasgow HB, Burkholder JM, Zhang C (2001) Comparative response to algal prey by Pfiesteria piscicida, Pfiesteria shumwayae and an estuarine 'lookalike' species. In: Hallegraeff GM, Blackburn S, Bolch C, Lewis R (eds) Proc 9th Int Conf Algal Blooms. Intergovernmental Oceanographic Commission of UNESCO, Paris, p 101-104

Rhodes LL, Adamson JE, Rublee PA, Schaefer EF (2006) Pfiesteria species (Pfiesteriaceae) in New Zealand. NZ J Mar Freshw Biol 40:211-220

Rublee PA, Kempton J, Schaefer E, Burkholder JM, Glasgow HB Jr, Oldach D (1999) PCR and FISH Detection Extends the Range of Pfiesteria piscicida in Estuarine Waters. Virginia J Sci 50:325-336

Rublee PA, Kempton JW, Schaefer EF, Allen C and 6 others (2001a) Use of molecular probes to assess geographic distribution of Pfiesteria species. Environ Health Perspect 109:765-767

Rublee PA, Kempton JW, Schaefer EF, Allen C, Burkholder JM, Glasgow HB, Oldach DW (2001b) Distribution of Pfiesteria sp. and an associated dinoflagellate along the US East Coast during the active season 1998 and 1999. In: Hallegraeff GM, Blackburn S, Bolch C, Lewis R (eds) Proc 9th Int Conf Harmful Algal Blooms. Intergovernmental Oceanographic Commission of UNESCO, Paris, p 89-91

Rublee PA, Allen C, Schaefer Rhodes EL, Adamson J, Lapworth C, Burkholder J, Glasgow H (2004) Global distribution of toxic Pfiesteria complex species detected by PCR asssay. In: Steidinger KA, Landsberg $\mathrm{JH}$, Tomas CR, Vargo G (eds) Harmful algae 2002. Intergovernmental Oceanographic Commission of UNESCO, Paris, p 320-322

Rublee RA, Remington DL, Schaefer EF, Marshall MM (2005) Detection of the dinozoans Pfiesteria piscicida and $P$. shumwayae: a review of detection methods and geographic distribution. J Eukaryot Microbiol 52:83-89

Seaborn DW, Seaborn AM, Dunstan WM, Marshall HG (1999) Growth and feeding studies on the algal feeding stage of a Pfiesteria-like dinoflagellate. Virginia J Sci 50:337-344 
Seaborn D, Dunstan W, Marshall H, Gordon A, Seaborn M (2001) Growth and toxicity studies of the dinoflagellates 'Cryptoperidiniopsis' sp., Gyrodinium galatheanum, and Pfiesteria piscicida. In: Hallegraeff GM, Blackburn S, Bolch C, Lewis R (eds) Proc 9th Int Conf Harmful Algal Blooms. Intergovernmental Oceanographic Commission of UNESCO, Paris, p 92-96

Sherr EB, Sherr BF (2002) Significance of predation by protists in aquatic microbial food webs. Antonie Leeuwenhoek 81:293-308

Springer JJ, Burkholder J, Shumway SE (1996) Effects of the toxic dinoflagellate, Pfiesteria piscicida, on juvenile bay scallops (Argopecten irradians, Lamarck). J Shellfish Res 15:530

Springer JJ, Shumway SE, Burkholder JAM, Glasgow HB (2002) Interactions between the toxic estuarine dinoflagellate Pfiesteria piscicida and two species of bivalve molluscs. Mar Ecol Prog Ser 245:1-10

Steidinger KA, Babcock C, Mahmoudi B, Tomas C, Truby E (1989) Conservative taxonomic characters in toxic dinoflagellate species identification. In: Okaichi T, Anderson DM, Nemoto T (eds) Red tides: biology, environmental science and technology. Elsevier, Amsterdam, p 285-288

Editorial responsibility: Urania Christaki, Wimereux, France
Steidinger KA, Burkholder JM, Glasgow HB Jr, Hobbs CW, Garrett JK, Truby EW, Noga EJ, Smith SA (1996) Pfiesteria piscicida gen. et sp. nov. (Pfiesteriaceae fam. nov.), a new toxic dinoflagellate with a complex life cycle and behavior. J Phycol 32:157-164

Steidinger K, Landsberg J, Richardson RW, Truby E and 10 others (2001) Classification and identification of Pfiesteria and Pfiesteria-like species. Environ Health Perspect 109: 661-665

Stoecker DK, Guillard RRL, Kavee RM (1981) Selective predation by Favella ehrenbergii (Tintinnida) on and among dinoflagellates. Biol Bull (Woods Hole) 160:136-145

Strathmann RR (1967) Estimating the organic carbon content of phytoplankton from cell volume or plasma volume. Limnol Oceanogr 12:411-418

Tengs T, Bowers HA, Glasgow HB Jr, Burkholder JM, Oldach DW (2003) Identical ribosomal DNA sequence data from Pfiesteria piscicida (Dinophyceae) isolates with different toxicity phenotypes. Environ Res 93:88-91

Tillmann U (2004) Interactions between planktonic microalgae and protozoan grazers. J Eukaryot Microbiol 51: $156-168$

Submitted: March 23, 2006; Accepted: June 29, 2006

Proofs received from author(s): September 19, 2006 